\title{
man \\ Mechanomimetic 3D Scaffolds as a Humanized In Vitro Model for Ovarian Cancer
}

\author{
Francesca Paradiso ${ }^{1,2,3} \mathbb{D}^{\text {, Stefania Lenna }}{ }^{1,2}$, S. Andrea Gazze ${ }^{3}$, Jezabel Garcia Parra ${ }^{3}$, Kate Murphy ${ }^{4}{ }^{(0}$, \\ Lavinia Margarit ${ }^{3}$, Deyarina Gonzalez ${ }^{3}$ (), Lewis Francis $^{3}$ and Francesca Taraballi $1,2, *$ (I)
}

1 Center for Musculoskeletal Regeneration, Houston Methodist Academic Institute, Houston Methodist Research Institute, 6670 Bertner Ave., Houston, TX 77030, USA; fparadiso@houstonmethodist.org (F.P.); slenna@houstonmethodist.org (S.L.)

2 Orthopedics and Sports Medicine, Houston Methodist Hospital, 6445 Main St., Houston, TX 77030, USA

3 Reproductive Biology and Gynaecological Oncology Group, Swansea University Medical School, Singleton Park, Swansea SA2 8PP, UK; s.a.gazze@swansea.ac.uk (S.A.G.); j.garciaparra@swansea.ac.uk (J.G.P.);

laviniamarg@doctors.org.uk (L.M.); d.gonzalez@swansea.ac.uk (D.G.); 1.francis@swansea.ac.uk (L.F.)

4 Department of Pathology, Singleton Hospital, Swansea Bay University Health Board, Swansea SA2 8QA, UK; kate.murphy@wales.nhs.uk

* Correspondence: ftaraballi2@houstonmethodist.org

check for

updates

Citation: Paradiso, F.; Lenna, S.;

Gazze, S.A.; Garcia Parra, J.; Murphy,

K.; Margarit, L.; Gonzalez, D.; Francis,

L.; Taraballi, F. Mechanomimetic 3D

Scaffolds as a Humanized In Vitro

Model for Ovarian Cancer. Cells 2022,

11, 824. https://doi.org/10.3390/

cells11050824

Academic Editors: Dong-Joo Cheon and John M. Lamar

Received: 3 February 2022

Accepted: 23 February 2022

Published: 26 February 2022

Publisher's Note: MDPI stays neutral with regard to jurisdictional claims in published maps and institutional affiliations.

Copyright: (c) 2022 by the authors. Licensee MDPI, Basel, Switzerland. This article is an open access article distributed under the terms and conditions of the Creative Commons Attribution (CC BY) license (https:// creativecommons.org/licenses/by/ $4.0 /)$.

\begin{abstract}
The mechanical homeostasis of tissues can be altered in response to trauma or disease, such as cancer, resulting in altered mechanotransduction pathways that have been shown to impact tumor development, progression, and the efficacy of therapeutic approaches. Specifically, ovarian cancer progression is parallel to an increase in tissue stiffness and fibrosis. With in vivo models proving difficult to study, tying tissue mechanics to altered cellular and molecular properties necessitate advanced, tunable, in vitro 3D models able to mimic normal and tumor mechanic features. First, we characterized normal human ovary and high-grade serous (HGSC) ovarian cancer tissue stiffness to precisely mimic their mechanical features on collagen I-based sponge scaffolds, soft (NS) and stiff (MS), respectively. We utilized three ovarian cancer cell lines (OVCAR-3, Caov-3, and SKOV3) to evaluate changes in viability, morphology, proliferation, and sensitivity to doxorubicin and liposomal doxorubicin treatment in response to a mechanically different microenvironment. High substrate stiffness promoted the proliferation of Caov-3 and SKOV3 cells without changing their morphology, and upregulated mechanosensors YAP/TAZ only in SKOV3 cells. After 7 days in culture, both OVCAR3 and SKOV3 decreased the MS scaffold storage modulus (stiffness), suggesting a link between cell proliferation and the softening of the matrix. Finally, high matrix stiffness resulted in higher OVCAR-3 and SKOV3 cell cytotoxicity in response to doxorubicin. This study demonstrates the promise of biomimetic porous scaffolds for effective inclusion of mechanical parameters in 3D cancer modeling. Furthermore, this work establishes the use of porous scaffolds for studying ovarian cancer cells response to mechanical changes in the microenvironment and as a meaningful platform from which to investigate chemoresistance and drug response.
\end{abstract}

Keywords: 3D model; extracellular matrix; collagen; matrix stiffness; cancer; microenvironment; nanoparticles; doxorubicin

\section{Introduction}

The microenvironment surrounding cancer cells has been shown to contribute to tumor progression at both biological and physical levels [1,2]. Indeed, tumor biophysics encompasses physical forces, such as compression, tension, hydrostatic pressure, and shear, all thought to be crucial factors in tumor microenvironment (TME) driven cancer cell sensing [3-5]. Alterations in extracellular matrix (ECM) composition and organization, as well as crosstalk with the surrounding physical and biochemical niche microenvironment, has been shown to drive cancer cell responses, such as proliferation, cytoskeleton 
distribution, migration, gene expression, and signal transduction [6-12]. Furthermore, mounting evidence suggest that not only the composition of the ECM, but also its stiffness, can significantly affect cancer cell responses to treatment and chemoresistance [13-15].

The field of cancer biomechanics aims to better understand not only how cancer cell behavior is affected by mechanical changes in the microenvironment, but also how tissue mechanical features can be exploited to detect specific disease stages, while enabling the discovery of potential new diagnostic tools and/or therapies [16]. The role of mechanical constrains in tumorigenesis has been well-studied in breast cancer, for example, where the stiffening and remodeling of the ECM accompany the promotion of breast carcinoma cell proliferation, and local tumor cell invasion and progression [17,18]. Indeed, increased density and reorganization of collagen fibrils around malignant breast tumors appears to facilitate local tumor cell invasion $[19,20]$. As a result, nonlinear optical imaging methods, such as multiphoton microscopy (MPM) and second harmonic generation (SHG) imaging, have been used to visualize local changes in collagen fibril density around invasive breast tumors [21].

Similar to breast cancer, epithelial ovarian cancer (EOC) evaluation with MPM and SHG imaging has revealed altered collagen fibril density and topology linked to increased stiffness and fibrosis, and associated with both primary and disseminated EOC [22-24]. Some evidence suggests that EOC tissue mechanical changes may also result from inflammation in the form of endometriosis $[25,26]$. The origin of ovarian carcinoma is still under debate, postulated to derive from any of three potential sites: the surfaces of the ovary, the fallopian tube, or the mesothelium-lined peritoneal cavity $[27,28]$. To invade the surrounding tissue and metastasize, ovarian carcinoma cells undergo an epithelial-to-mesenchymal transition; then, carried by the peritoneal fluid (ascites), they form multicellular aggregates (metastatic unit) called spheroids [29], overcome anoikis, and attach preferentially onto the abdominal peritoneum or omentum, a principal physiologic target for EOC dissemination $[30,31]$. The most common form of ovarian carcinoma is high-grade serous (HGS), usually diagnosed at an advanced stage (stage III, 70\% of cases [32]), and is an inherently aggressive malignancy, thus accounting for the majority of ovarian cancer deaths [33,34]. At this late disease stage, chemotherapy resistance occurs, for reasons as yet unknown [35].

Carboplatin with paclitaxel represents the standard first-line chemotherapy regimen for ovarian cancer patients; however, only $40-60 \%$ of patients will achieve complete remission, with a high risk of neurotoxicity, which can persist for more than a year after the treatment $[36,37]$. Consequently, other more efficacious or tolerable options were evaluated, i.e., pegylated liposomal doxorubicin (PLD). This is an anthracycline encapsulated within a sterically stabilized liposome that increases the agent's circulating half-life in the body and limits its toxicity profile, significantly lowering cardiac toxicity and myelosuppression compared to conventional doxorubicin [38]. It is now a widely used agent for the treatment of patients with recurrent or refractory ovarian cancer, although there are not many implications for its use as a monotherapy regimen [39-41].

Increased matrix stiffness is closely linked to tumor progression [42,43]; however, the malignancy of metastatic ovarian cancer has been shown to increase on soft matrices. Indeed, ovarian cancer cells on soft matrices are more proliferative and more resistant to standard chemotherapeutic drugs [31]. Since ovarian cancer mechanics and biophysics studies have resulted in contradictory findings, the exploration of mechanotransduction within ovarian cancer remains understudied [25]. Furthermore, many of the mechanical studies in EOC have been performed on spheroids and 2D polyacrylamide gels [44,45]; alternatively, the inclusion of mechanical constraints while designing an in vitro model to fully mimic native tumor tissue biology, requires the use of 3D culture platforms [46]. Rapid advances in 3D cell culture systems now allow for the recapitulation of cell differentiation and tissue organization, opening new possibilities for studying the underlying biochemical and biomechanical signals between cancer cells and the TME [47,48].

Tissue engineering (TE) describes the process of fabricating functional 3D tissues using a combination of scaffolds and/or devices with cells to facilitate essential cellular 
functions, such as growth, differentiation, migration, and organization [49]. In the field of regenerative medicine, these 3D devices aim to replace or "regenerate" human cells, tissues, or organs to restore or establish normal function [50]. As established by decades of research on tissue engineering (TE) and manufacturing, in order to create an effective 3D construct, three crucial components (called the TE triad) are needed: a relevant selection of cells, a biomaterial scaffold that provides the structural support for cell attachment and guides tissue development [51,52], and chemicals and biophysical signals that crosstalk to ultimately recreate tissue [53,54]. Typically, in tissue engineering, three individual groups of biomaterials are used in the fabrication of scaffolds: ceramics, synthetic polymers, and natural polymers [49]; these groups have been explored for a variety of applications, such as tissue engineering in bone [55], skin [56], cardiac tissue [57], skeletal muscle [58], and cancer models [59]. Natural biomaterials are bioactive, biodegradable, and allow host cells to produce their own extracellular matrix and remodel the scaffold [49]. However, depending on the scaffold employed, they generally possess poor mechanical properties, which limits their use in, for example, load bearing orthopedic applications.

For its high biocompatibility and bioactivity, the natural polymer collagen was selected for scaffold fabrication in this research. Collagen is the most abundant structural protein in the connective tissues, and its homology across species provides low antigenicity and high biocompatibility [60,61]; in humans, collagen represents one-third of the total protein content in the body [62]. Over the last two decades, four major scaffolding approaches for TE have evolved: pre-made porous scaffolds, decellularized extracellular matrix (ECM), cell sheets with self-secreted ECM, and cell encapsulation in a self-assembled hydrogel matrix [63]. Among these, the most common approach is the use of a pre-made porous scaffold [54], since it harbors a number of advantages: it has the most diversified range of biomaterials available to use, natural or synthetic [48]; precise architectural features and microstructures can be incorporated [64]; physicochemical characteristics can be tuned to mimic the physical properties of native tissues [65]. Specifically, matrix stiffness cues can be easily tuned in porous collagen type I-based interconnected scaffold systems by varying crosslinking types or percentages [66-69] to control porosity and fiber organization, resulting in a tunable system for 3D mechanical studies [70,71]. Indeed, easy to reproduce, convenient to handle, and amenable to large-scale use, porous scaffolds now have a wide scope of applications [70,72-74]. However, only a few solid tumors have been tested using these approaches, i.e., breast, prostate, and glioblastoma, mainly investigated using chitosan-alginate- or chitosan-hyaluronic acid-based scaffolds [75-81].

Using a sponge scaffold 3D collagen-based culture system, we investigate the role of substrate stiffness in affecting EOC cell behavior and chemoresistance in vitro. Following the assessment of fresh OC tissue to define the stiffness parameters of both peritoneum/cancer and normal ovarian mechanical features, we mimic the stiff (MS, metastatic scaffold) and soft (NS, normal scaffold) tissue properties using 3D porous matrices, testing their utility and suitability for reproducing in vivo tissue mechanics while serving as platform for drug testing. Detailed mechanical tests are performed using multiple technologies, from atomic force microscopy (AFM), easily run on the cell/tissue surface [82], to rheology and tensile/compression testing [83], performed on the bulk material. Three human EOC cell lines derived from the ovary (OVCAR-3, Caov-3) or peritoneal ascites (SKOV3) are seeded and cultured in 3D, and monitored for their ability to sense, colonize, proliferate, and remodel the collagen-rich scaffold environment. Following successful culture, EOC cell matrix models are tested for their sensitivity to doxorubicin and liposomal doxorubicin [84]. Our results show how proliferation and mechanosensing response(s) to microenvironment stiffness is EOC cell line specific and, on the other hand, higher sensitivity to chemotherapy is a common effect promoted by stiff matrices across all cell lines used. The combined data presented support the adoption of sponge scaffold models for cancer research to closely study tissue mechanical cues and their effect on ovarian cancer cells, delineating microenvironment components and testing new treatment strategies in a cost-effective and timely manner. 


\section{Materials and Methods}

\subsection{Scaffold Preparation}

Chemicals were purchased from Sigma-Aldrich. The scaffolds were synthesized from type I bovine collagen (Viscofan, Cáseda, Spain) and fabricated with the freeze-dry technique. Briefly, we prepared an acetic collagen slurry $(200 \mathrm{mg}$ per $\mathrm{mL}$, which was precipitated to a $\mathrm{pH}$ of 5.5 with $\mathrm{NaOH}(2 \mathrm{~N})$. The wet slurry was crosslinked in an aqueous solution of $0.1 \% w / v$ (normal scaffold) and $1 \% w / v$ (metastatic scaffold) BDDGE at $4{ }^{\circ} \mathrm{C}$ for $24 \mathrm{~h}$. Finally, the slurry was washed with Milli-Q water (EMD Millipore, Burlington, Massachusetts) and casted onto a 48-well plate and freeze-dried via an optimized freezing and heating ramp (from $25^{\circ} \mathrm{C}$ to $-25{ }^{\circ} \mathrm{C}$ and from $-25{ }^{\circ} \mathrm{C}$ to $25{ }^{\circ} \mathrm{C}$ for 50 min under vacuum conditions, $p=0.20$ mbar) to obtain the desired pore size and porosity.

\subsection{Atomic Force Microscopy}

The atomic force microscope used in this experiment was the Bio-Catalyst AFM (Bruker, Burlington, MA, USA). A spherical cantilever (Novascan, Chicago, IL, USA) was used for the force measurement. For biopsy samples, the QNM in fluid mode was used with a borosilicate tip ( $5 \mu \mathrm{m}$ in diameter). For scaffolds, a silica bead (5 $\mu \mathrm{m}$ in diameter) was mounted onto the end of the cantilever. The spring constant of the cantilever was $0.06 \mathrm{~N}$. Prior to the AFM experiment, both the spring constant and sensitivity of the cantilever were calibrated under thermal tune conditions with the controlling software (Bruker, Catalyst NanoScope 8.15 SR3R1, http:/ / nanophys.kth.se/nanophys/facilities/nfl/afm/icon/brukerhelp/Content/SoftwareGuide/NanoScope815CoverPage.htm, accessed on 3 February 2022). For the AFM experiment, both biopsies and scaffolds were embedded in OCT and cryosectioned at $20 \mu \mathrm{m}$ section thickness. The samples were pre-coated on a glass slide and kept at $-80{ }^{\circ} \mathrm{C}$. Then, samples were carefully moved into a $60 \mathrm{~mm}$ dish on the AFM scanning stage. A volume of $3 \mathrm{~mL}$ phosphate-buffered saline (PBS) or media was pre-injected into the dish after sample incubation for $5 \mathrm{~min}$ at room temperature. For force measurement, we kept the ramping size at $10 \mu \mathrm{m}$. All experiments were conducted at room temperature $\left(22^{\circ} \mathrm{C}\right)$. Young's modulus was calculated from the force curves with NanoScope Analysis 1.40 (Bruker, v1.40r1, http: / / nanoscaleworld.bruker-axs.com/nanoscaleworld/forums/t/812.aspx, accessed on 3 February 2022), with 3 to 5 spots randomly tested per sample and recorded, and at least 50 force curves acquired from each spot. For Young's modulus calculations, extended ramp force curves, and a linearized model (Hertzian, spherical) were used.

\subsection{Rheology}

Wet and dry scaffolds of $1 \mathrm{~mm}$ thickness and $8 \mathrm{~mm}$ diameter were analyzed using an Anton Paar/MCR 302 rheometer equipped with an aluminum $8 \mathrm{~mm}$ insert plate. Both empty scaffolds and cellularized scaffolds collected at days 1-7 were characterized. An amplitude sweep test ( $\log$ ramp $0.001 \%$ to 10\%, angular frequency of $10 \mathrm{~Hz}, 25$ recorded points, $\mathrm{T}$ of $37^{\circ} \mathrm{C}$ ) was used to verify the range of linear viscoelasticity. Frequency response was measured by frequency sweep tests in the range 1000 to 0.1 rad per s (shear strain of $0.1 \%, 40$ data points, $\mathrm{T}$ of $37^{\circ} \mathrm{C}$ ). Storage modulus and loss moduli measures were reported as 3-sample averages collected at 1 rad per s angular frequency.

\subsection{Compression Test}

NS and MS scaffolds of $0.5 \mathrm{~cm}$ thickness were soaked in PBS and loaded onto a UniVert Mechanical Test System. A load cell of $1 \mathrm{~N}$ was calibrated and used to perform a compression test with a stretch magnitude of 35\%, stretch duration of $60 \mathrm{~s}$, and relaxation time of $60 \mathrm{~s}$. For each condition, 3 replicates were analyzed.

\subsection{Scanning Electron Microscopy}

The morphology of the scaffold was characterized by SEM and the pore size determined by ImageJ (US National Institutes of Health). Scaffolds were coated with $7 \mathrm{~nm}$ of Pt/Pl (FEI Company, Hillsboro, OR, USA, Nova NanoSEM 230) for SEM examination. The 
pore diameter of scaffolds was measured from SEM images, and 3 images from each of 3 areas were used for each scaffold at the same magnitude. For each image, porosity analysis was performed using 'analyze particles' measurement in ImageJ software (National Institutes of Health and the Laboratory for Optical and Computational Instrumentation (LOCI, University of Wisconsin), version 1.41, https://imagej.nih.gov/ij/, accessed on 3 February 2022).

\subsection{Fourier Transform Infrared Spectroscopy}

The samples were analyzed in attenuated total reflection (ATR) mode at $2 \mathrm{~cm}^{-1}$ resolution 64 times over the range of $500-4000 \mathrm{~cm}^{-1}$ using a Nicolet 6700 spectrometer (Thermo Fisher Scientific, Waltham, MA, USA). The ATR/Fourier transform infrared spectroscopy (FTIR) spectra were reported after background subtraction, baseline correction, and normalization on Amide I. Graphs reported a range of $500-1800 \mathrm{~cm}^{-1}$ wavelength.

\subsection{Cell Culture}

OVCAR-3, Caov-3, and SKOV3 cells were purchased from ATCC. Cultures were established in standard growth medium, as suggested on the ATCC website, composed of RPMI-1640 Medium with $0.01 \mathrm{mg}$ per $\mathrm{mL}$ bovine insulin and fetal bovine serum to a final concentration of 20\% for OVCAR-3, Dulbecco's Modified Eagle's Medium with fetal bovine serum to a final concentration of $10 \%$ for Caov-3, and McCoy's 5 a Medium modified with fetal bovine serum to a final concentration of $10 \%$ for SKOV3. All growth media were supplemented with $1 \%$ penicillin (100 UI per $\mathrm{mL}$ )-streptomycin $(100 \mathrm{mg}$ per $\mathrm{mL}$ ).

Adherent cells were detached from plates using trypsin before reaching confluence $(80 \%)$ and subsequently re-plated for culture maintenance. For maintenance of cultures, cells were incubated at $37{ }^{\circ} \mathrm{C}$ in a humidified atmosphere $(90 \%)$ with $5 \% \mathrm{CO}_{2}$. Medium was changed twice per week. When seeded onto scaffolds, ovarian cancer cells were harvested and re-suspended in cell culture medium. A $20 \mu \mathrm{L}$ drop of medium containing $1 \times 10^{5}$ cells was seeded on the center of each scaffold and kept in an incubator for $30 \mathrm{~min}$. Culture medium was then added to each well.

\subsection{Biopsy Samples}

Ethical approval for this study was obtained from NHS HRA Wales6 REC (15/WA/0065) to collect tissue samples from ovarian cancer patients and non-cancer controls. Formal written consent was obtained from all patients at the time of recruitment into the study.

A total of 6 ovarian biopsies were collected for this study and processed for AFM analyses. The histological evaluation of the ovarian biopsies and the cancer diagnosis was confirmed by the pathology department as part of the patient's routine clinical care. Three were used as normal ovary controls as they were obtained from normal contralateral ovaries of patients diagnosed with benign pathologies. The remaining 3 ovarian biopsy tissue samples represented HGSC stage IIIc (as summarized in Table 1).

Table 1. Patient demographics for patient biopsy samples.

\begin{tabular}{ccccccc}
\hline $\begin{array}{c}\text { Pat. } \\
\text { Code }\end{array}$ & Age & $\begin{array}{c}\text { Stage } \\
\text { Diagnosed }\end{array}$ & Diagnosis & Surgery & $\begin{array}{c}\text { Ovarian Mass } \\
\text { Location }\end{array}$ & $\begin{array}{c}\text { Biopsy Location for AFM } \\
\text { Analysis }\end{array}$ \\
\hline ctrl 1 & 66 & pelivic mass & benign fibroma & primary & left & right (contralateral normal ovary) \\
\hline ctrl 2 & 77 & pelivic mass & benign adenoma & primary & right & left (contralateral normal ovary) \\
\hline ctrl 3 & 71 & pelivic mass & benign fibroma & primary & left & right (contralateral normal ovary) \\
\hline OC 1 & 71 & HGSC IIIc & HGSC IIIc & interval & left/right & left \\
\hline OC 2 & 69 & HGSC IIIc & HGSC IIIc & interval & left/right & left \\
\hline OC 3 & 59 & HGSC IIIc & HGSC IIIc & interval & left/right & right \\
\hline
\end{tabular}




\subsection{HEE Staining of Patient Biopsy Samples}

Paraffin sections were cut at $4 \mu \mathrm{m}$ thickness. Hematoxylin and eosin staining was performed using the ST Infinity H\&E Staining System (Leica Biosystems, Wetzlar, Germany) in Leica Autostainer ST5010 XL. Paraffin was melted prior to staining by heating the slides at $60{ }^{\circ} \mathrm{C}$ for $30 \mathrm{~min}$, then slides were deparaffinized by performing $3 \times 2 \mathrm{~min}$ washes in xylene, $3 \times 1$ min washes in $100 \%$ ethanol, and $1 \times 1$ min wash in $95 \%$ ethanol, before rinsing with tap water. Slides were incubated for $30 \mathrm{~s}$ in Hemalast, for $5 \mathrm{~min}$ in hematoxylin, and were rinsed for $1 \mathrm{~min}$ with tap water. Next, slides were incubated for $30 \mathrm{~s}$ in a differentiator and $1 \mathrm{~min}$ in bluing agent, with each step followed by a tap water rinse for $1 \mathrm{~min}$ then $95 \%$ ethanol for $1 \mathrm{~min}$. Slides were stained with eosin for $30 \mathrm{~s}$, dehydrated in $95 \%$ ethanol for $1 \mathrm{~min}, 4 \mathrm{~min}$ in $100 \%$ ethanol, and $2 \times 1 \mathrm{~min}$ in $100 \%$ ethanol, and cleared for $3 \times 2 \mathrm{~min}$ in xylene. Every step after the initial heating of the slides was conducted at room temperature.

\subsection{Microscopy}

\subsubsection{Live-Death Imaging}

After 7 days of culture, scaffolds with cells were incubated with $2 \mu \mathrm{L}$ of $50 \mu \mathrm{M}$ calcein AM working solution and $4 \mu \mathrm{L}$ of ethidium homodimer- 1 stock and incubated for $20 \mathrm{~min}$ at $37^{\circ} \mathrm{C}$ protected from the light. After several washes with warm media, cells were analyzed by Keyence BZX800 using a $4 \times$ objective and a final stich process to show the entire scaffold surface.

\subsubsection{F-Actin Imaging}

After 7 days of culture, scaffolds were collected and washed with 1\% PBS. After fixation with $4 \%$ paraformaldehyde for $10 \mathrm{~min}$ at room temperature, cellularized scaffolds were washed twice with PBS $+0.1 \%$ Tween and permeabilized using Triton X-100 $0.1 \%$ in PBS for $10 \mathrm{~min}$ at room temperature. Incubation with phalloidin-555 (Aa34055, Thermo Fisher Scientific, 1:100) and Draq-5 5 Mm (62251, Thermo Fisher Scientific, 1:20) was performed for $2 \mathrm{~h}$ at room temperature protected from light. After washing with PBS $+0.1 \%$ Tween twice, imaging was conducted with the Nikon A1 confocal imaging system, using a $20 \times$ objective. Volume recording was performed on z-stacks of $200 \mu \mathrm{m}$ and step size of $10 \mu \mathrm{m}$.

\subsection{Flow Cytometry \\ Cell Survival and Death Quantification}

After 7 days of TGF $\beta 1$ treatment, scaffolds were incubated for $10 \mathrm{~min}$ in trypsin under shaking conditions; subsequently, scaffolds were removed, and cell pellets were collected after centrifugation and washed with PBS. Cells were incubated with $2 \mu \mathrm{L}$ of $50 \mu \mathrm{M}$ calcein AM working solution and $4 \mu \mathrm{L}$ of ethidium homodimer- 1 stock, and incubated for $20 \mathrm{~min}$ at $37^{\circ} \mathrm{C}$ protected from the light. After several washes with warm media, cells were analyzed by flow cytometry using BD FACS Fortessa.

\subsection{Reverse Transcription Quantitative PCR}

Reverse transcription PCR was performed on cells grown in 2D culture and on 3D scaffolds after 7 days. Scaffolds with cells were washed in PBS and incubated with $1 \mathrm{~mL}$ TRIzol RT for $10 \mathrm{~min}$ under shaking conditions. After removing the scaffolds, $200 \mu \mathrm{L}$ of chloroform was added and samples were inverted for $15 \mathrm{~min}$, incubated on ice for $2 \mathrm{~min}$, and centrifuged at $12,000 \times \mathrm{g}$ for $15 \mathrm{~min}$ at $4{ }^{\circ} \mathrm{C}$. The aqueous phase was transferred to a $1.5 \mathrm{~mL}$ tube and $500 \mu \mathrm{L}$ of isopropyl alcohol added, before incubating for $10 \mathrm{~min}$ at $4{ }^{\circ} \mathrm{C}$ and centrifuging $12,000 \times g$ for $10 \mathrm{~min}$ at $4{ }^{\circ} \mathrm{C}$. After washing the pellet twice with $1 \mathrm{~mL} 70 \%$ ethanol, it was aspirated and allowed to dry before resuspending in $20 \mu \mathrm{L}$ of water. Total RNA (500 ng) was reverse transcribed into cDNA using the Bio-Rad iScript ${ }^{\mathrm{TM}}$ cDNA Synthesis Kit. Quantitative PCR was performed using the TaqMan ${ }^{\mathrm{TM}}$ Fast Advanced Master Mix on a StepOnePlus Real-time PCR System (Applied Biosystems, Waltham, MA, USA). Expression of YAP1 (Hs00902712) and WWTR1 (reported as TAZ, Hs00210007_m1) was detected using TaqMan ${ }^{\circledR}$ Gene Expression Assays. 18S ribosomal RNA was used as an internal reference for normalization. Analysis was performed using the relative $\Delta \Delta C T$ method. 


\subsection{MTT Assay Protocol for Cell Viability and Proliferation}

To perform this test, SKOV3 and Caov-3 cells were seeded at a concentration of 8000 cells per well in 96-well plates, while 20,000 OVCAR-3 cells were seeded per well in a final volume of $100 \mu \mathrm{L}$ per well. MTT was added to achieve a final concentration of $0.5 \mathrm{mg}$ per mL MTT in normal media. After incubating $2 \mathrm{~h}$ at $37^{\circ} \mathrm{C}$, MTT was removed and $100 \mu \mathrm{L}$ DMSO added before mixing contents for $30 \mathrm{~min}$ on an orbital shaker protected from light. Absorbance was measured at $590 \mathrm{~nm}$.

\subsection{CellTiter-Glo ${ }^{\circledR}$ Luminescent Cell Viability Assay}

For the proliferation assay, ovarian cancer cells were grown on scaffolds for 10 days and analysis performed at 4 time points (day 1 , day 4 , day 7 , day 10). For cytotoxic evaluation of doxorubicin, ovarian cancer cells were grown on scaffolds for 7 days, and then treated with free doxorubicin (DOXO), doxorubicin-loaded liposomes (DOXO-LIPO), or empty liposomes for $72 \mathrm{~h}$. To perform the analysis, a volume of CellTiter-Glo ${ }^{\circledR}$ Reagent (Promega, Madison, WI, USA) equal to the volume of cell culture medium present in each well/scaffold was added. Contents were mixed for $10 \mathrm{~min}$ on an orbital shaker to induce cell lysis, protected from light. The plate was incubated at room temperature for 25 min to stabilize luminescent signal, before transferring $100 \mu \mathrm{L}$ (or a 1:10 dilution in media for high signals) in white opaque-walled 96-well plates to measure luminescence.

\subsection{Assembly and Physical Characterization of Liposomes}

To assemble liposomes, $20 \mathrm{mg}$ of total lipids including DPPC, DSPC, DOPX, and cholesterol (molar ratio 5:1:3:1) were dissolved in methanol-chloroform solution (1:3 v/v) to a final volume of $1 \mathrm{~mL}$. The solvent was evaporated via a rotary evaporator (Buchi Labortechnik AG, Flawil, Switzerland) for $20 \mathrm{~min}$ at $45^{\circ} \mathrm{C}$ to form a thin lipid film. The film was hydrated with $1 \mathrm{~mL}$ sterile water to assemble empty liposomes or $250 \mathrm{mM}$ ammonium sulfate for liposomes to be loaded with doxorubicin. The $1 \mathrm{~mL}$ solution was incubated for $3 \mathrm{~min}$ at $45^{\circ} \mathrm{C}$ followed by $3 \mathrm{~min}$ vortexing. Lipid suspension was forced through a polycarbonate filter (200 nm; GE Osmonics Labstore, Minnetonka, MN, USA) 10 times under nitrogen gas pressure at $45{ }^{\circ} \mathrm{C}$ (filter was replaced after 5 extrusions). Size, zeta potential, and polydispersity index (PDI) were measured using dynamic light scattering. After the nanoparticles (NPs) were fabricated, they were loaded into dialysis floaters in order to exchange the outside buffer with $0.9 \% \mathrm{NaCl}$ overnight. Lipid formulation was then incubated at $1: 1 \mathrm{v} / \mathrm{v}$ for $2 \mathrm{~h}$ at $45^{\circ} \mathrm{C}$ with $1 \mathrm{~mL}$ of $2 \mathrm{mg}$ per $\mathrm{mL}$ doxorubicin hydrochloride (Sigma-Aldrich, St. Louis, MO, USA, D1515) dissolved in DDW. Only DOXO-LIPO NPs were loaded again into dialysis floaters in order to exchange the outside buffer with $0.9 \mathrm{NaCl}$ overnight. NanoSight NS300 (Malvern, Worcestershire, UK) for both empty and loaded NPs was performed as the final step to measure lipid NPs concentration.

\subsection{Evaluation of Doxorubicin Encapsulation Efficiency and Release}

Doxorubicin encapsulation and drug release analysis was performed using a Tecan Microplate Reader. For the doxorubicin release experiment, DOXO-LIPO NPs were incubated with PBS $+10 \%$ FBS (50:50) at $37^{\circ} \mathrm{C}$ under shaking conditions and samples were collected and analyzed after $0.5,1,1.5,2,4,5,8,24,48 \mathrm{~h}$. For DOXO encapsulation, DOXO-LIPO NPs were diluted in water to 1:200 and mixed (1:1 v/v) with $0.2 \%(v / v)$ triton $x-100$ (overall doxorubicin) or water (released doxorubicin) in a black 96-well plate for $5 \mathrm{~min}$ at room temperature under shaking conditions. Doxorubicin fluorescence was read at excitation $480 \mathrm{~nm} / \mathrm{emission} 590 \mathrm{~nm}$ and cyclophosphamide (Cy) fluorescence at 5.5 excitation $650 \mathrm{~nm} /$ emission $700 \mathrm{~nm}$.

\subsection{Statistical Analysis}

All data were obtained from at least 3 independent experiments and expressed as mean \pm standard deviation, with $n$ indicating the number of replicates. The two-tailed Student's t test with Welch's correction or an ANOVA test was used to determine differences between groups. Results were considered to be statistically significant at $p$-value $<0.05$. The 
statistical analysis was processed with GraphPad Prism 6 Software (GraphPad, San Diego, CA, USA).

\section{Results}

\subsection{Scaffold Characterization}

Patient biopsy mechanics, derived from both high-grade serous carcinoma (HGSC) stage III and normal ovary tissues, were analyzed at the nanoscale using AFM. A 5.5-fold increase in stiffness was observed between HGSC IIIa $(0.11 \pm 0.034 \mathrm{MPa})$ and normal ovary $(0.02 \pm 0.016 \mathrm{MPa})$ tissues $(p<0.05$; Figure 1A, Figure S1). The AFM data from native tissues were successfully mimicked in a 3D collagen type I-based scaffold model. Using $1 \%$ and $0.1 \% w / v$ BDDGE crosslinkers achieved a higher stiffness for the metastatic scaffolds (MS, $0.144 \pm 0.010 \mathrm{MPa}$ ) compared with the normal scaffolds (NS, $0.015 \pm 0.0003 \mathrm{MPa}$ ), respectively ( $p<0.05$; Figure $1 \mathrm{~B})$. H\&E staining of patient biopsy samples was performed (Figure S2), reporting a high presence of ECM/fibrotic tissue in the HGSC IIIc-derived samples (Figure S2B).

A
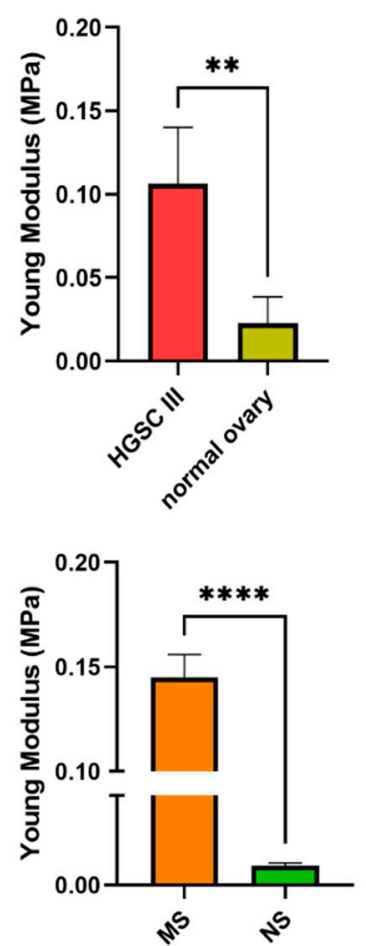

C

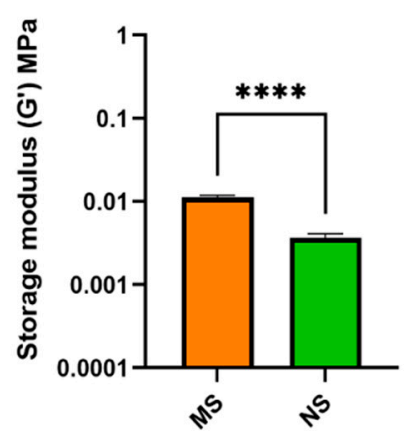

D

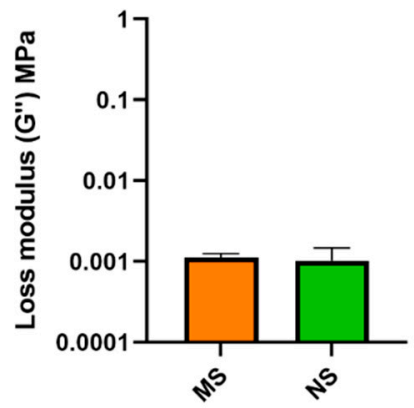

$\mathbf{E}$

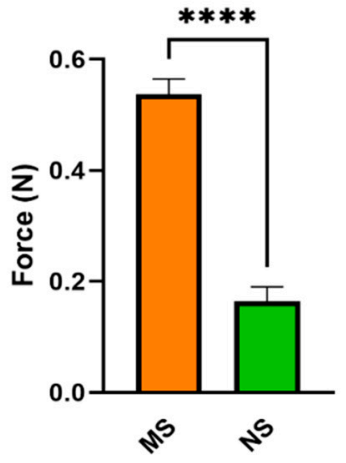

Figure 1. Mechanical features of normal and cancer tissues are mimicked in a 3D collagen-based in vitro system using different percentages of crosslinker 1,4-butanediol diglycidyl ether (BDDGE). (A) Young's modulus (MPa) analysis of 3 HGCS III and 3 normal patient-derived biopsies by AFM. (B) Young's modulus (MPa) analysis of MS and NS scaffolds by AFM. (C) Rheology analysis of MS and NS scaffold storage moduli (G', MPa). (D) Rheology analysis of MS and NS scaffold loss moduli $\left(\mathrm{G}^{\prime \prime}, \mathrm{MPa}\right)$. (E) Compression test analysis of MS and NS scaffolds. Data are mean + standard deviation $(n=3)$. Student's $t$ test with Welch's correction, ${ }^{* * * *} p<0.0001,{ }^{* *} p<0.01$.

In addition to AFM, shear rheometry was performed on the fabricated scaffolds to gain knowledge on the resulting bulk tissue mechanics characterizing our model [85]. The scaffold elastic component, called the storage modulus $\left(G^{\prime}\right)$, at $1 \mathrm{~Hz}$ was significantly increased in the MS $(0.011 \pm 0.0006 \mathrm{MPa})$ compared to the NS $(0.0036 \pm 0.00046 \mathrm{MPa})$ scaffolds, showing a 3-fold increase in elastic properties; alternatively, the viscous component, called the loss modulus $\left(G^{\prime \prime}\right)$, was comparable between the two scaffold types (MS: $0.0011 \pm 0.0001 \mathrm{MPa}$; NS: $0.0010 \pm 0.0004 \mathrm{MPa}$ ) (Figure 1C,D). Subsequent compressive tests were carried out to evaluate the compressive strength and stiffness of the scaffolds. The results, summarized in 
Figure 1E, showed that higher force was required to compress MS $(0.54 \pm 0.028 \mathrm{~N})$ compared to NS $(0.16 \pm 0.025 \mathrm{~N})$ scaffolds.

The porous structure of MS and NS scaffolds after freeze-drying was determined by SEM imaging (Figure 2A). At lower magnification, the sample structures were composed of interconnected pores with boundaries defined by sheet-like structures of fibrillar collagen. At higher magnification, the typical fibrous substructure of collagen sponges can be appreciated. Porosity measurements showed that MS and NS scaffolds exhibited a comparable average pore size of approximately $2500 \mathrm{\mu m}^{2}$, corresponding to an average diameter of $56.4 \mu \mathrm{m}$, with a comparable percentage area of $30 \mu \mathrm{m}^{2}$ covered by pore structures, and a pore circularity of approximately 0.37 (Figure 2B).

A
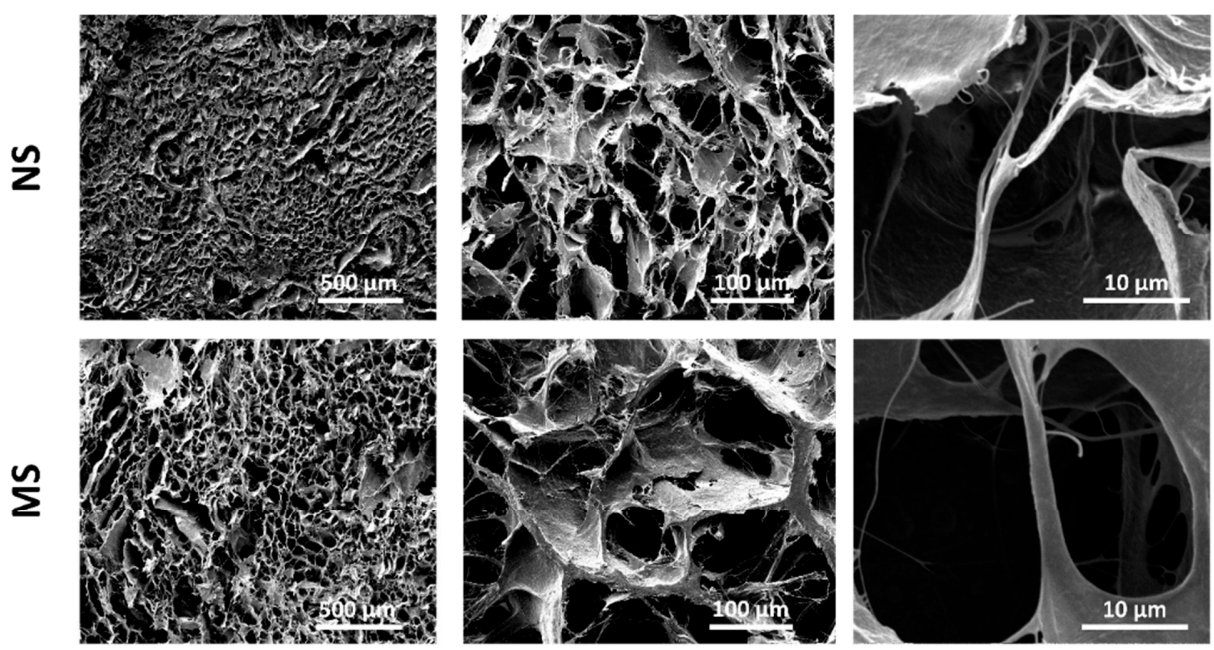

B
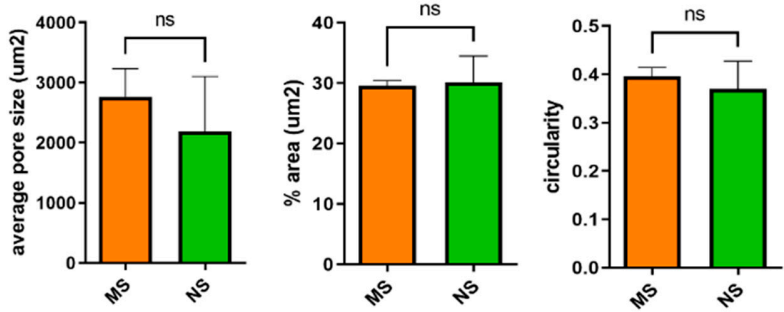

C

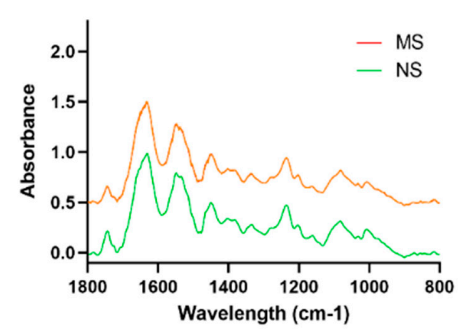

Figure 2. NS and MS scaffolds showed common pore sizes, pore coverage, and composition. (A) SEM imaging of NS and MS scaffolds at different magnifications. (B) SEM analysis of average pore size $\left(\mu \mathrm{m}^{2}\right), \%$ area covered by pore structures, and circularity. Student's t test with Welch's correction performed (ns: not significant). (C) FTIR spectra of MS and NS scaffolds. The spectra highlighted the presence of typical collagen Amide I, Amide II, and Amide III.

FTIR was used to characterize scaffold composition after crosslinking. FTIR spectra, reported in Figure 2C, showed the characteristic collagen vibration peaks, such as Amide I (1700-1600 $\left.\mathrm{cm}^{-1}\right)$ and Amide II (1600-1500 $\left.\mathrm{cm}^{-1}\right)$, related to the stretching vibration of $\mathrm{C}=\mathrm{O}$ bonds, and to $\mathrm{C}-\mathrm{N}$ stretching and $\mathrm{N}-\mathrm{H}$ bending vibrations, respectively, for both scaffold types. The samples contained $\mathrm{C}=\mathrm{O}, \mathrm{C}-\mathrm{N}$, and $\mathrm{N}-\mathrm{H}$ bonds. The Amide III region (approximately $1200-1300 \mathrm{~cm}^{-1}$ ) is related to $\mathrm{C}-\mathrm{N}$ and $\mathrm{C}-\mathrm{C}$ stretching, $\mathrm{N}-\mathrm{H}$ bonds, and $\mathrm{CH} 2$ wagging from the glycine backbone and proline side chain.

\subsection{Viability, Morphology, and Proliferation of Ovarian Cancer Cells on MS and NS Scaffolds}

We employed three cell lines derived from the ovary (OVCAR-3, Caov-3) or peritoneal ascites (SKOV3) of EOC [86] to test their phenotypical, behavioral, and transcriptional differences in response to microenvironment stiffness. First, cell death was monitored after 7 days of culture on NS and MS scaffolds, using calcein/ethidium bromide staining, assessed by epifluorescence 
microscopy, and quantified by flow cytometry (Figure 3). All three cell lines were able to attach to, and colonize, the scaffolds, as reported by the 3D maximum intensity projection based on three layers collected per scaffold (Figure 3A,C,E). When analyzed quantitatively for viability, calcein-positive OVCAR-3, Caov-3, and SKOV3 percentages were, respectively, $84.29 \% \pm 6.5 \%$ (Figure 3A), 88.75\% $\pm 10.4 \%$ (Figure 3C), and 80.83\% $\pm 5.8 \%$ (Figure 3E) on MS and $91.39 \% \pm 7.04 \%, 93.01 \% \pm 5.3 \%$, and $87.95 \% \pm 4.3 \%$ on NS scaffolds, with no statistical differences in cell viability between the two scaffold types. No morphological changes were detected after 7 days of culture in the cancer cells lines on the scaffolds, as shown by F-actin immunofluorescence staining. The OVCAR-3 cells maintained their cuboidal shape (Figure 3B), Caov-3 cells their spindle-shaped morphology (Figure 3D), and SKOV3 cells their elongated spindle-shaped morphology (Figure 3F).

A
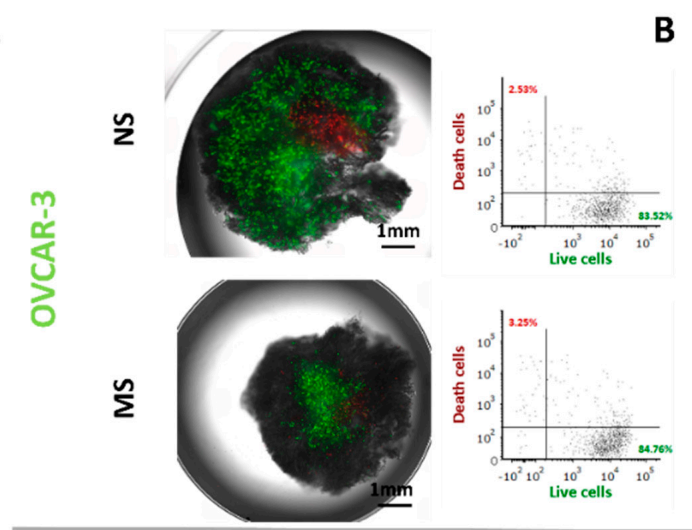

C

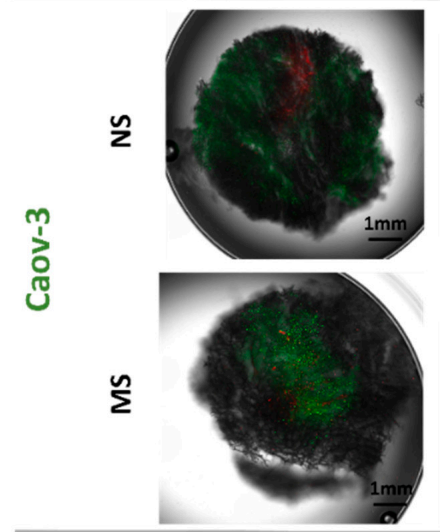

$\mathbf{E}$

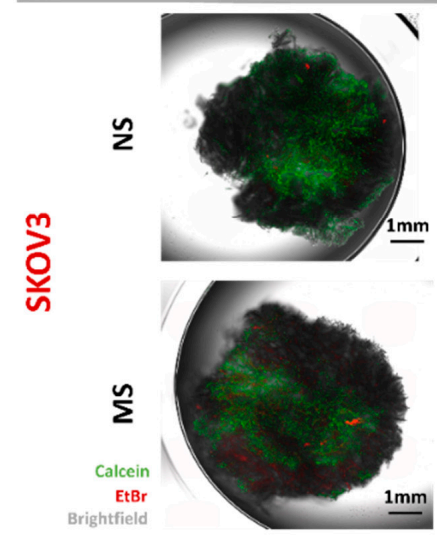

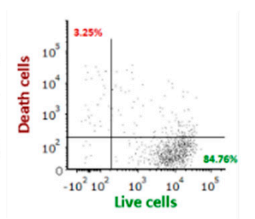

B
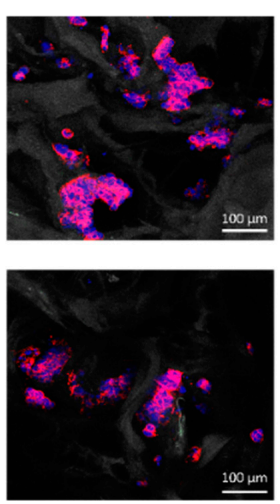

D
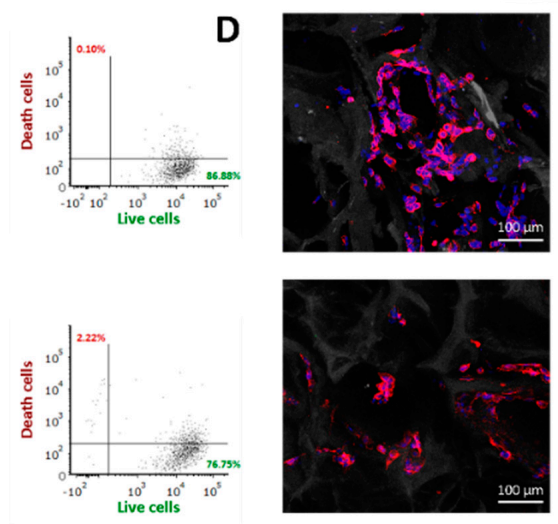

$\mathbf{F}$
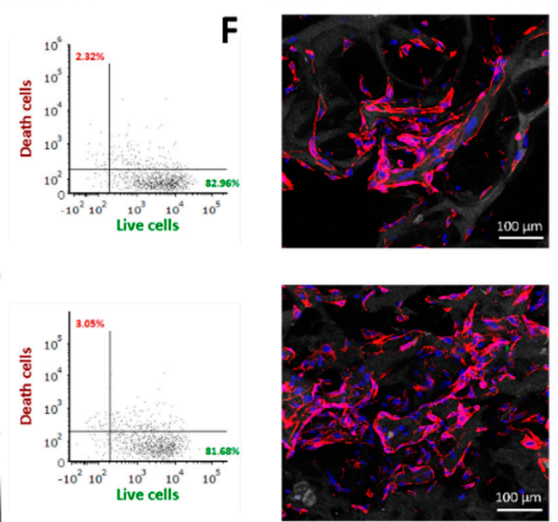
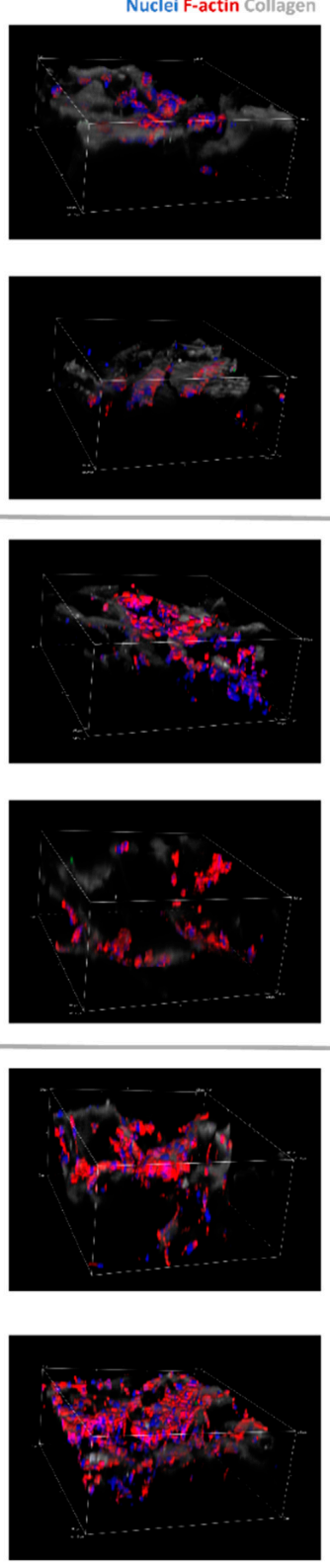

Figure 3. Ovarian cancer cell lines were viable and did not change their morphology when cultured on both MS and NS scaffolds. Cell death staining analyzed with fluorescence microscopy and flow cytometry of (A) OVCAR-3, (C) Caov-3, and (E) SKOV3 cells. Immunofluorescence staining of F-actin and DAPI in (B) OVCAR-3, (D) Caov-3, and (F) SKOV3 cells. Analysis and imaging was performed after 7 days of culture. In lateral projection pictures, Z-size is $200 \mu \mathrm{m}$ and step size is $10 \mu \mathrm{m}$. 
Cancer cell proliferation rate was assessed by CellTiter-Glo ${ }^{\circledR}$. The OVCAR-3 proliferation rates showed no differences between MS and NS scaffolds until day 10 of culturing, at which point, OVCAR-3 proliferation was observed to be higher on NS scaffolds when compared to their MS counterparts ( $8.6 \pm 0.19$ and $7.7 \pm 0.5$, respectively) (Figure $4 \mathrm{~A}$ ). The Caov-3 cell line showed a 1.3-, 1.2-, and 1.2-fold increase in proliferation at days 4, 7, and 10, respectively, when cultured on the MS compared to the NS scaffolds (Figure 4B). The SKOV3 cell line showed higher proliferation rates on MS scaffolds from day 7, exhibiting a 1.08-fold increase in proliferation at day 7 and 1.05-fold increase at day 10 on MS compared to NS scaffolds (Figure 4C).

A

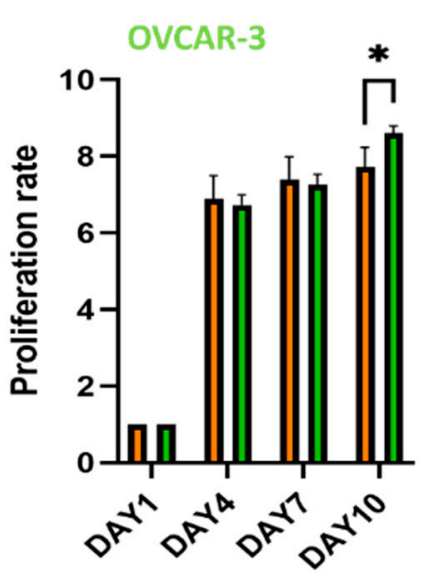

B

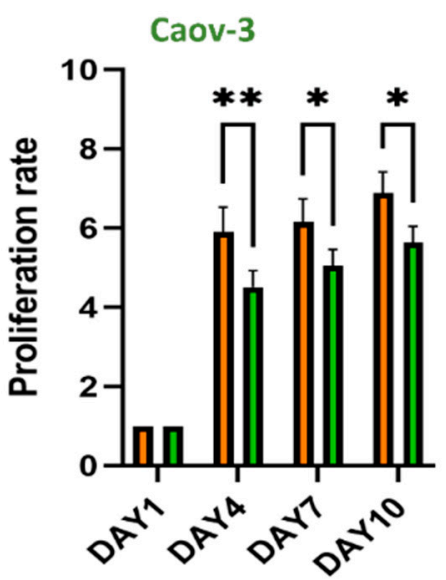

C

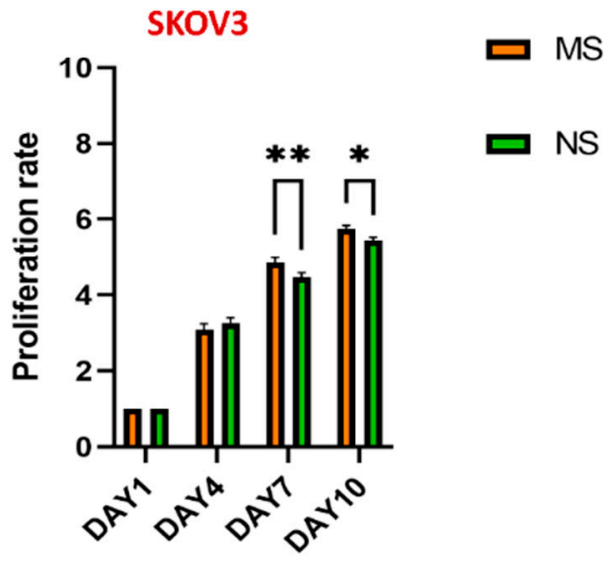

Figure 4. SKOV3 and Caov-3 cells proliferate more rapidly on MS scaffolds, while OVCAR-3 cells proliferate more rapidly on NS scaffolds. CellTiter-Glo ${ }^{\circledR}$ analysis of ovarian cancer cell proliferation rate from day 1 to day 10 on MS and NS scaffolds for (A) OVCAR-3, (B) Caov-3, and (C) SKOV3 cells. Data are mean + standard deviation $(n=3)$. Statistical analysis performed with two-way ANOVA. ** $p<0.01, * p<0.05$.

\subsection{Mechanosensing by Ovarian Cancer Cells and the Impact of the Microenvironment Mechanics}

To understand how ovarian cancer cells culturing on 3D scaffolds influence overall scaffold tissue mechanics, we evaluated the bulk mechanics, using rheometry, at day 1 and day 7 of culture (Figure 5A-G). After 1 day of culturing, MS and NS scaffolds still harbored significant differences in their storage moduli $(p<0.01$ and $p<0.05)$; for OVCAR-3-cultured scaffolds, these were $0.093 \pm 0.041 \mathrm{MPa}$ for MS and $0.012 \pm 0.002 \mathrm{MPa}$ for NS; for Caov-3, these were $0.032 \pm 0.005 \mathrm{MPa}$ for MS and $0.012 \pm 0.004 \mathrm{MPa}$ for NS; and for SKOV3, these were $0.039 \pm 0.011 \mathrm{MPa}$ for MS and $0.012 \pm 0.0004 \mathrm{MPa}$ for NS. A decrease in MS storage moduli was observed at day 7 for the OVCAR-3 culture (MS $0.030 \pm 0.006 \mathrm{MPa}$, NS $0.005 \pm 0.004 \mathrm{MPa}$ ) and SKOV3 culture (MS $0.021 \pm 0.002 \mathrm{MPa}, \mathrm{NS} 0.007 \pm 0.001 \mathrm{MPa}$ ) (Figure $5 \mathrm{~A}, \mathrm{C}, \mathrm{E}$ ); in contrast, no differences in storage moduli at day 7 were observed for Caov-3 (MS $0.029 \pm 0.007 \mathrm{MPa}$, NS $0.012 \pm 0.0004 \mathrm{MPa})(p<0.01)$. Regarding SKOV3 no significant differences were recorded for loss moduli at day 7. At day 1, loss moduli for OVCAR-3 were MS $0.015 \pm 0.010 \mathrm{MPa}$, NS $0.002 \pm 0.0001 \mathrm{MPa}$; for Caov-3 were MS $0.004 \pm 0.001 \mathrm{MPa}$, NS $0.002 \pm 0.001 \mathrm{MPa}$; and for SKOV3 were MS $0.005 \pm 0.002 \mathrm{MPa}$, NS $0.002 \pm 0.0001 \mathrm{MPa}$ (all $p<0.05$ ). These values at day 7 were: OVCAR-3 MS $0.004 \pm 0.001 \mathrm{MPa}$, NS $0.001 \pm 0.001 \mathrm{MPa}$; Caov-3 MS $0.004 \pm 0.001 \mathrm{MPa}$, NS $0.002 \pm 0.0001 \mathrm{MPa}(p<0.05)$; SKOV3 MS $0.003 \pm 0.0001 \mathrm{MPa}$, NS $0.001 \pm 0.0001 \mathrm{MPa}$ (Figure 5B,D,F). 
A

OVCAR-3

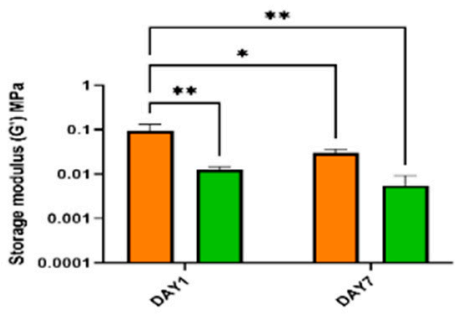

C

Caov-3

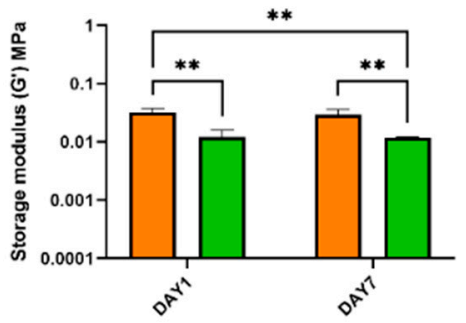

E

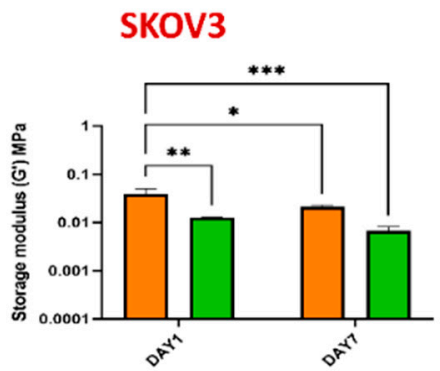

B

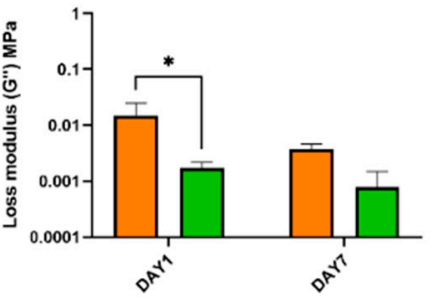

D

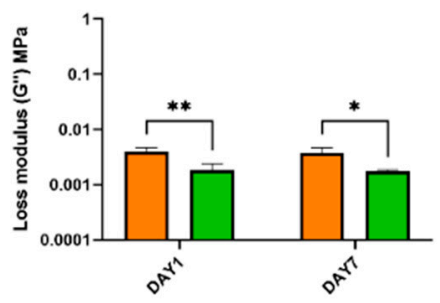

$\mathbf{F}$

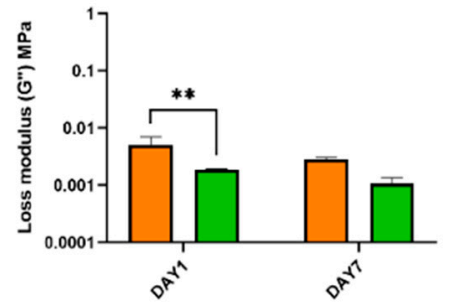

G

OVCAR-3
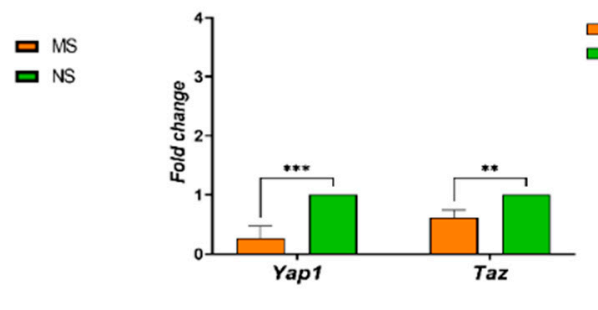

$\square$ MS
$\square$ NS

H

Caov-3

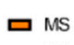

口NS

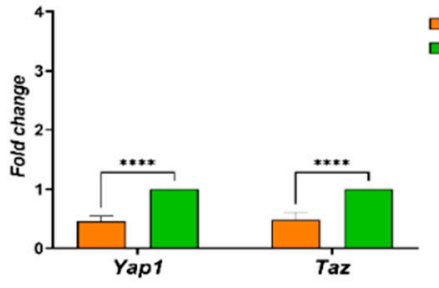

I

SKOV3
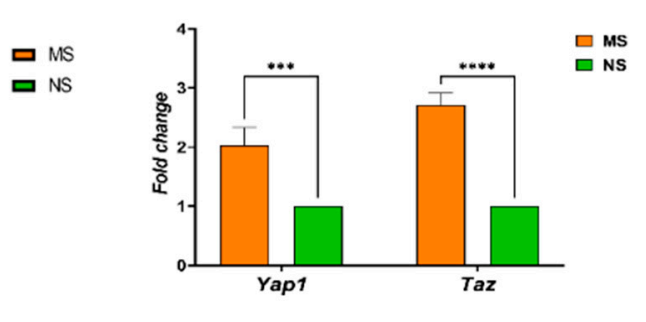

Figure 5. Bulk mechanical properties are slightly changed by OVCAR-3 and SKOV3, while Hippo pathway activation is specific to the SKOV3 cell line. Rheology analysis of storage modulus $\left(G^{\prime}\right)$ in MS and NS scaffolds at days 1 and 7 of OVCAR-3 (A), Caov-3 (C), and SKOV3 (E) culture. Rheology analysis of loss modulus ( $G^{\prime \prime}$, right) in MS and NS scaffolds at days 1 and 7 of OVCAR-3 (B), Caov-3 (D), and SKOV3 (F) culture. mRNA expression of mechanosensing-related genes (Yap and Taz) in OVCAR-3 (G), Caov-3 (H), and SKOV3 (I)-cultured scaffolds at day 7. Data normalized to NS scaffolds. Data are mean + standard deviation $(n=3)$. Statistical analysis performed with two-way ANOVA. ${ }^{* * * *} p<0.0001,{ }^{* * *} p<0.001,{ }^{* *} p<0.01,{ }^{*} p<0.05$.

Mechanical changes in the microenvironment can strongly affect cells at the transcriptomic level through a process called mechanosensing [47]. We evaluated the expression of two master mechanosensors and transcriptional activators, Yap1 and Taz, which are essential for triggering cancer initiation and growth of most solid tumors [87]. Among the ovarian cancer cell lines tested, only SKOV3 reported a 2.2-fold increase in Yap1 expression and a 2.7-fold increase in Taz expression on MS compared to NS scaffolds, supporting mechanosensing-related pathway activation promoted by increased substrate rigidity (Figure 5G,H,I). This suggests a differential and specific oncogenic role of YAP [88], and its potential use as predictive factor [89], for rapidly proliferating and highly metastatic SKOV3 cell lines. Interestingly, a large body of evidence indicates that YAP/TAZ activation and overexpression is implicated in resistance to targeted therapies, chemotherapy (such as DNA damaging agents), radiation, and immunotherapies [90]. 


\subsection{D In Vitro Cytotoxic Effect of Free Doxorubicin and Doxorubicin-Loaded Liposomes}

To evaluate the link between stiffness of the substrate, mechanosensing, and resistance to chemotherapy, we employed our 3D model platforms to test ovarian cancer cell sensitivity to mainline chemotherapeutic treatments, doxorubicin (DOXO) and doxorubicin-loaded liposome (DOXO-LIPO). Similar formulations of doxorubicin have been reported to be effective, with tolerable side-effects in either combination therapy with carboplatin or in monotherapy for recurrent or platinum-resistant ovarian cancer [91].

The physicochemical features of conventional liposomes $[92,93]$ were retained when loaded with DOXO. DOXO encapsulation did not significantly affect the size and polydispersity of DOXO-LIPO. Indeed, compared to empty liposomes (hydrodynamic size $=184 \pm 2.0 \mathrm{~nm}$; $\mathrm{PDI}=0.15 \pm 0.151$ ), DOXO encapsulation did not alter nanovesicle diameter (hydrodynamic size $=183.5 \pm 2.8 \mathrm{~nm}$ ), and only slightly decreased size distribution $(\mathrm{PDI}=0.08 \pm 0.015)$ to values that are still below 0.2 , thus indicating a high size homogeneity. Surface charge was similar between empty liposomes $(Z$ potential $=-8.4 \pm 0.6)$ and DOXO-LIPO $(Z$ potential $=-8.42 \pm 0.94)$ (Figure S3A).

The DOXO loading efficiency into liposomes was 93.9\% $\pm 3.63 \%$ (Figure S3B), with a release kinetic of DOXO from liposomes of $16.5 \%$ after $8 \mathrm{~h}$, and a $56 \%$ DOXO release after $72 \mathrm{~h}$ (Figure S3C). The in vitro cytotoxicity of free DOXO, DOXO-LIPO, and empty liposomes was tested against OVCAR-3, Caov-3, and SKOV3 cell lines grown in 2D culture, on NS and MS scaffolds. In 2D culture, the MTT assay was used to evaluate cell viability and proliferation, and in 3D culture, growth inhibition was assessed using CellTiter-Glo ${ }^{\circledR}$. After normalization against untreated cells, we observed a similar effect of free DOXO and DOXO-LIPO in reducing all ovarian cancer cell viability in 2D, while empty liposomes did not affect cell viability after either 48 or $72 \mathrm{~h}$ of treatment. Interestingly, OVCAR-3 cells in 2D were the most resistant to treatment after 48 and $72 \mathrm{~h}$ in the lower dose range, showing reductions in cell viability at $72 \mathrm{~h}$ of 64,43 , and $35.8 \%$ for DOXO, and 75,46 , and $42.6 \%$ for DOXO-LIPO, at concentrations of $0.0625,0.125$, and $0.25 \mu \mathrm{M}$, respectively (Figure S4A). Meanwhile, at the same concentrations, Caov- 3 cells showed reductions in cell viability of 30,21 , and $11 \%$ for DOXO, and 45,35 , and $21 \%$ for DOXO-LIPO (Figure S4B), and SKOV3 cells showed reductions of 21,10 , and $8 \%$ for DOXO, and 30,10 , and $8 \%$ for DOXO-LIPO (Figure S4C).

On the 3D in vitro scaffolds, cells were initially treated with a dose ranging from 0.25 to $5 \mu \mathrm{g}$ per $\mathrm{mL}$ DOXO and DOXO-LIPO (data not shown), and we chose to focus our analysis on a low and high dose close to the $\mathrm{IC}_{50}$ value $(0.25$ and $1 \mu \mathrm{g}$ per $\mathrm{mL}$ ) (Figure S5A-C). Overall, both 0.25 and $1 \mu \mathrm{g}$ per $\mathrm{mL}$ of DOXO and DOXO-LIPO had a higher cytotoxic effect on 2D cultures rather than 3D MS and NS scaffolds. DOXO-LIPO and DOXO showed comparable effects among all cell lines tested, with the only exception of OVCAR-3 cells in 3D culture, in which free DOXO had a greater cytotoxic effect compared to DOXO-LIPO (DOXO and DOXO-LIPO, $1 \mu$ g per $\mathrm{mL}$; MS 20\% and 70\% cell viability; NS 46\% and 98\% cell viability) (Figure 6A,B). Interestingly, Caov-3 was more sensitive than the other two cell lines to both DOXO and DOXO-LIPO at $1 \mu \mathrm{g}$ per $\mathrm{mL}$, exhibiting a cytotoxic effect comparable to the one obtained in 2D (DOXO 13\%, 36\%, and 30\%; DOXO-LIPO 29\%, 34\%, and 37\%; for 2D culture, MS and NS, respectively) (Figure 6C,D). Finally, SKOV3 showed DOXO and DOXO-LIPO cytotoxic effects at $1 \mu \mathrm{g}$ per $\mathrm{mL}$ on MS (33\% and 50\% cell viability) and NS (57\% and $63 \%$ cell viability) scaffolds, respectively (Figure 6E,F). Empty liposomes had minimal effect on the proliferation of all cancer cell lines (Figure S4). 
A

\section{OVCAR-3}

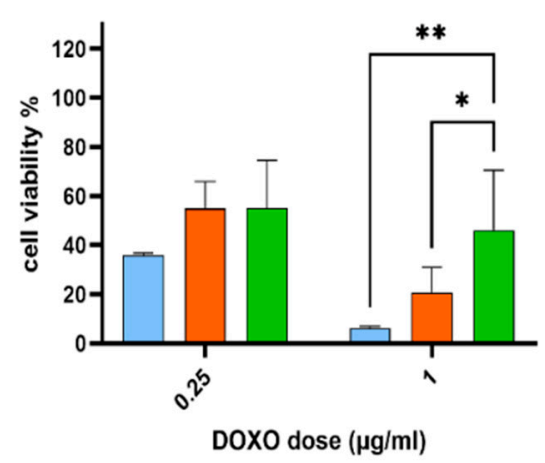

C

\section{Caov-3}

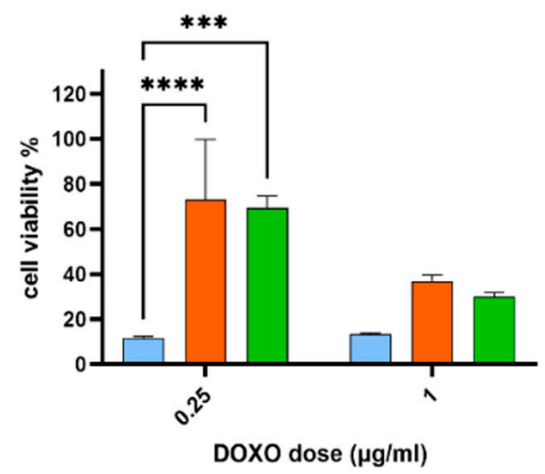

E

\section{SKOV3}

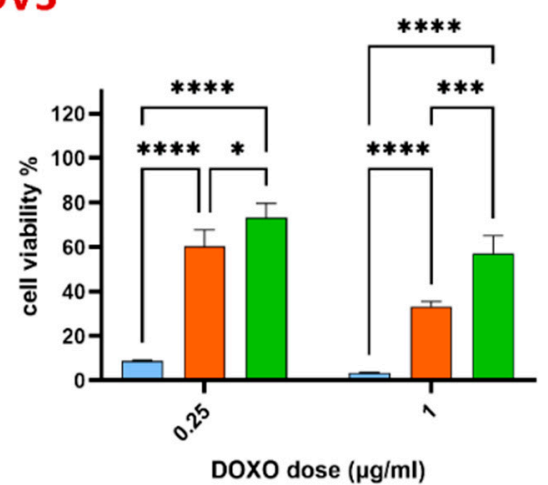

B

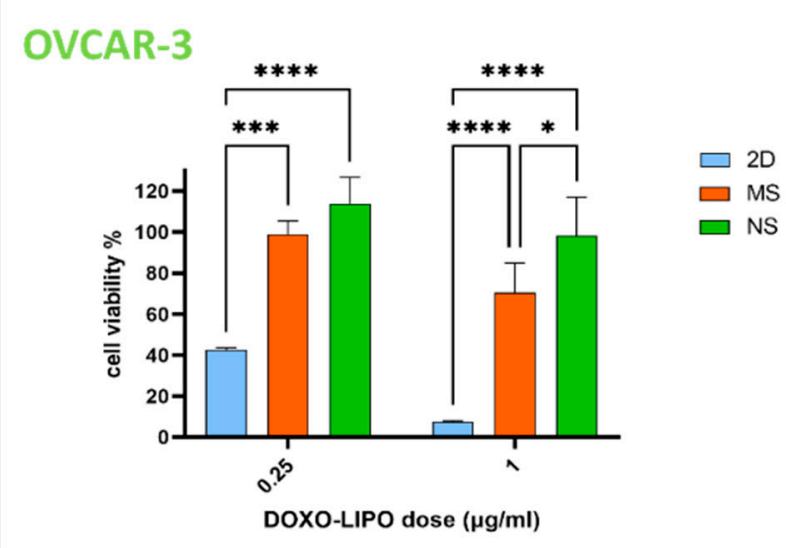

D

\section{Caov-3}

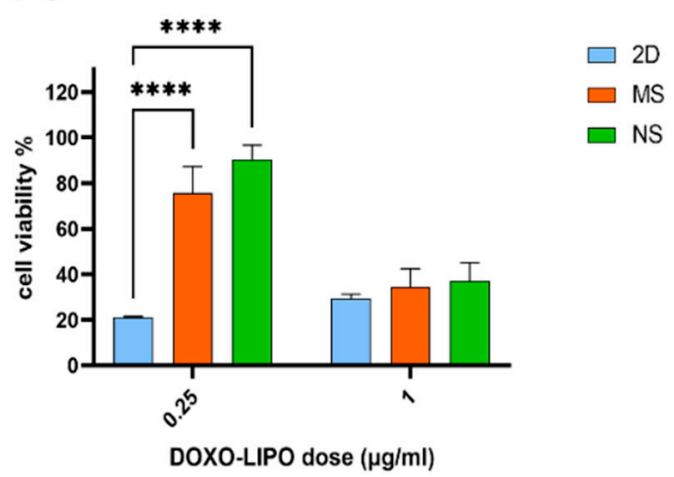

F

\section{SKOV3}

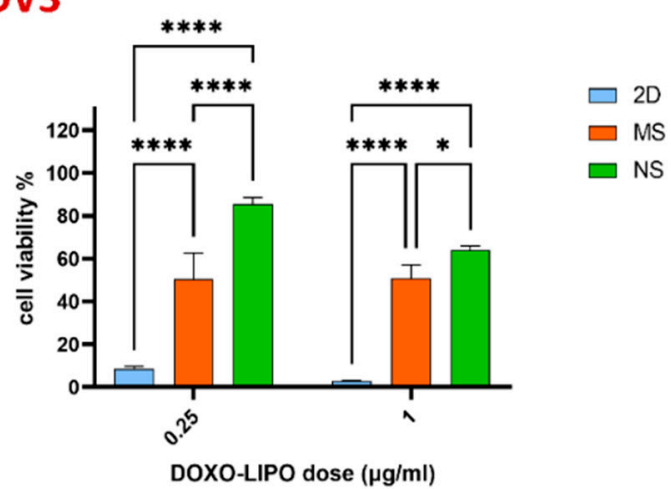

Figure 6. DOXO and DOXO-LIPO cytotoxic effects on ovarian cancer cell lines grown in 2D culture and on 3D MS and NS scaffolds. MTT and CellTiter-Glo ${ }^{\circledR}$ analysis of cell viability under 0.25 and $1 \mu \mathrm{g} / \mathrm{mL}$ DOXO and DOXO-LIPO treatment for OVCAR-3 (A,B), Caov-3 (C,D), and SKOV3 (E,F) ovarian cancer cell lines. Data are mean + standard deviation $(n=3 / 5)$. Statistical analysis performed with two-way ANOVA. ${ }^{* * * *} p<0.0001,{ }^{* * *} p<0.001,{ }^{* *} p<0.01,{ }^{*} p<0.05$. This section may be divided by subheadings. It should provide a concise and precise description of the experimental results, their interpretation, as well as the experimental conclusions that can be drawn.

\section{Discussion}

From a biophysical standpoint, solid tumor cancers have been shown to share physical characteristics; however, these are affected by specific mechanical cues linked to the tissue 
of origin [12,94-96]. For example, brain tumors are soft, whereas pancreatic tumors are rigid $[13,97]$. In such tissues, the inputs conveyed from the surrounding microenvironment are transmitted through surface receptors to the cellular compartments, and ultimately the cell nucleus, where they can influence gene expression and promote disease development and differentiation $[98,99]$. Tunable collagen sponge models allow cancer cell proliferation, morphology, migration, and drug response to be monitored in differential mechanical and biophysical contexts. In line with this, the use of 3D matrices to build physically meaningful platforms for drug testing is essential, since cells grown in 2D dish cultures experience a different force pattern, which could impact drug treatment outcome evaluation.

The NS and MS scaffold 3D in vitro model mimics the difference in stiffness between normal ovarian tissue and pathological HGSC stage III-derived tissue, respectively. After successfully mimicking in vivo stiffness on scaffolds MS (0.144 $\pm 0.010 \mathrm{MPa})$ and NS $(0.015 \pm 0.0003 \mathrm{MPa})$, we zoomed out from the AFM analysis, to evaluate the scaffolds bulk mechanic characteristics using rheology. A systematic mechanical characterization of the bulk tissue mechanics of patients' biopsy samples, or having the diagnostic tools able to detect changes in patients' tissue mechanics, could provide guidelines for clinical mechanopathology evaluation [85], ultimately helping doctors during diagnosis or deciding which tumors are most likely to develop chemoresistance, improving prognosis. Rheological analysis confirmed the results detected using AFM, reporting that MS scaffolds $(0.011 \pm 0.0006 \mathrm{MPa})$ were stiffer than NS scaffolds $(0.0036 \pm 0.00046 \mathrm{MPa})$, harboring a 3-fold increase in the storage modulus.

Our results are in line with previous research that analyzed tumor stiffness in vivo. For example, researchers employed supersonic shear wave elastography in a patient-derived xenograft (PDX) mouse model engrafted with HGSOC tumors isolated from patients, recording a significant increase in tumor stiffness (120 to $140 \mathrm{kPa}$ ) over time in mesenchymal HGSOC, while stiffness remained low (60 kPa maximum) in non-mesenchymal tumors. In high-grade serous ovarian cancers (HGSOC), representing the vast majority (75\%) of total ovarian cancers, the "fibrosis" or "mesenchymal" HGSOC molecular subtype has been identified in all studies, and is systematically associated with poor patient survival. It is characterized by high stromal content composed of myofibroblasts and ECM proteins, such as collagen and fibronectin, which are major causes of tumor stiffness [100]. In the same study, in few cases, the authors observed a new tumor nodule emerging from a stiff mesenchymal tumor, interestingly, the new nodule-of small size-was softer than the established initial tumor, suggesting tumor proliferation could originate in an initial soft state. Our data are in line with observations made in other cancer types. In breast cancer, malignant tissue is typically stiffer than its normal counterpart, with studies showing that normal breast tissue is 20 times softer than its neoplastic counterpart [101]; in addition, the elastic moduli of healthy thyroid tissue $(9.0-11.4 \mathrm{kPa})$ can increase by a full order of magnitude, up to $44-110 \mathrm{kPa}$, in patients with papillary adenocarcinoma [102]. Furthermore, the storage modulus of MS and NS scaffolds spans within the range of stiffness reported in the literature referring tissue/organ stiffness, ranging from $0.2-64 \mathrm{kPa}$ [103-105].

To test the mechanoresponsive potential of ovarian cancer malignancy, we selected three adenocarcinoma ovarian cancer cell lines: OVCAR-3 and Caov-3, derived from the ovary, and SKOV3, derived from ascitic fluid from post-chemotherapy patients. OVCAR-3 and Caov-3 possess TP53 mutations and substantial copy-number changes, which are key characteristics of HGSC, whereas SKOV3, based on its genetic profile, is categorized as non-serous [106,107]. Although these cell lines can be divided into different categories by their mutation profiles, their behaviors in vitro do not necessarily segregate the same way and, most interestingly, the cell lines do not all behave as expected based on their putative identity. Indeed, cell lines derived from non-serous carcinomas (e.g., SKOV3) were shown to migrate more quickly, and were more likely to invade into Matrigel and collagen I substrates than cell lines derived from high-grade serous carcinomas (e.g., OVCAR-3) [108]. Furthermore, other researchers found that SKOV3 cells had high tumorigenicity when injected intraperitoneally, whereas OVCAR-3 cells had low tumorigenicity when inoculated 
in nude mice over 6 weeks [109]. For this reason, we selected relevant HGSC and nonserous tumor-derived ovarian cancer cell lines to investigate mechanosensing behavior in response to different 3D biomechanic scaffolds. All the cell lines employed in our study successfully colonized, and were viable on both MS and NS scaffolds with no changes in morphology. However, looking at the migration depth in the scaffolds recorded by immunofluorescence staining, SKOV3 and Caov-3 showed higher invasiveness compared to OVCAR-3. Indeed, previous findings suggest that changes in stiffness of the cancer cell niche, as would be encountered by disseminated or metastatic OCCs, represents the mechanism to further promote EMT [15]. A significant difference was recorded in the proliferation rate, showing higher proliferation of OVCAR-3 on NS, while both Caov-3 and SKOV3 had higher proliferation rates on MS, suggesting higher responsiveness to rigid substrates. The higher rate of proliferation of OVCAR-3 and SKOV3 compared to Caov-3 resulted in a lower storage modulus after 7 days of culturing for MS, suggesting a link between cell proliferation and softening of the scaffolds recorded with rheometry. This phenomenon could be linked to two phenomena reported in literature. First, cancer cells are physically softer than normal cells $[110,111]$, and metastatic cancer cells are more mechanically compliant than their non-metastatic counterparts [112,113], contributing to the overall softening of the tissue. Second, previous findings suggest that a reduction in the stiffness of the cancer cell niche, as would be encountered by disseminated or metastatic OCCs, is a mechanism used to promote EMT [15], suggesting that the progressive softening of the matrix is a crucial step to promote metastasis.

Yorkie-homologues YAP (Yes-associated protein) and TAZ (transcriptional coactivator with PDZ-binding motif, also known as WWTR1) are transcriptional coactivators pervasively activated in human malignancies. Their activation in cancer cells impacts the behavior of cancer cells themselves by regulating their capacity to proliferate and adjust their metabolism to the altered cellular context, promoting the acquisition of stem-like properties, drug resistance, and migratory capacity that allow tissue invasion and metastatic dissemination. Interestingly, in the present study, YAP/TAZ are sensors of the structural and mechanical features of the cell microenvironment, including changes in mechanotransduction, inflammation, oncogenic signaling, and inhibition of the Hippo pathway [114,115]. Many correlations between high YAP and TAZ expression with poor patient outcome were reported for breast, colorectal, liver, and pancreatic cancers [87]; specifically, TAZ is thought to play an important role in breast cancer progression, with both mRNA and protein expression reported to be preferentially higher in triple-negative breast cancer than in the other subclasses [116-119]. Previous research reported that SKOV3 cells express low levels of endogenous YAP (and low activity) compared to Caov3 and OVCAR3 cells, which instead showed higher levels of both YAP expression and activity [120]. Interestingly, we observed that, while OVCAR-3 and Caov-3 downregulated YAP/TAZ expression on MS scaffolds, SKOV3 cells increased the expression of both markers on MS compared to NS scaffolds, suggesting a specific YAP/TAZ upregulation linked to a high stiffness microenvironment.

Aside from intrinsic molecular mechanisms [121], tumor chemoresistance is also affected by the biochemical and physical properties of the tumor microenvironment [122-124]. Specifically, the chemotherapeutic response of ovarian cancer cells in vitro is markedly affected by substrate stiffness; for example, during an evaluation of ovarian cancer tumor response to standard chemotherapeutic drugs (cisplatin and paclitaxel), antiproliferation effects were directly proportional to the stiffness of the substrate, thus, ovarian cancer cell lines grown on softer substrates with a lower elastic modulus were less sensitive to chemotherapeutic agents [15].

First-line management for ovarian cancer consists of surgery plus platinum-based combination chemotherapy, typically cisplatin or carboplatin, with the addition of a taxane, either paclitaxel or docetaxel [125]. Nevertheless, more than $70 \%$ of patients experience relapse after first-line therapy [126]. For patients that experience partially platinum-sensitive relapse (progression within 6 to 12 months after the last platinum-based chemotherapy treatment), the treatment has not yet been standardized [127-131]. 
Approved by the US Food and Drug Administration (FDA) in 1995, Doxil (doxorubicin $\mathrm{HCl}$ liposome injection, Tibotec Therapeutics, Division of Ortho Biotech Products, L.P.) was the first nanodrug marketed in the United States for the treatment of ovarian cancer in women for which the disease has progressed or recurred after platinum-based chemotherapy [132]. Many clinical trials showed response rates, progression-free survival, and overall survival similar to other platinum-based combinations, although with a more favorable toxicity profile and convenient dosing schedule when Doxil was tested $[133,134]$.

In line with these results, we tested the cytotoxic effects of free DOXO and DOXOLIPO on cis-platinum-resistant SKOV3 [135], OVCAR-3 [136], and Caov-3 [137] cell lines grown in 2D and on 3D MS and NS scaffolds. We reported a higher resistance to treatment in $3 \mathrm{D}$ vs. $2 \mathrm{D}$ culturing conditions, further stressing the importance of adopting $3 \mathrm{D}$ models to perform more reliable in vitro drug screening and dosing. Furthermore, among the different ovarian cancer cell lines, Caov-3 was more sensitive to both DOXO and DOXOLIPO treatment, pointing out the necessity to include many different cell lines or primary cells when performing cancer studies evaluating potential patient-treatment responses. Finally, both OVCAR-3 and SKOV3 showed a higher resistance to treatment when grown on NS scaffolds, and a more sensitive phenotype when grown on stiffer MS scaffolds, thus confirming a previous study reporting cell growth inhibition by doxorubicin in response to ECM rigidity [138].

\section{Conclusions}

To summarize, the inclusion of physical parameters in 3D in vitro model design will help configure a microenvironment closer to native tissues, which could sustain meaningful cell culture conditions for cancer research and drug testing. Envisioning a clinical application, the use of patient-derived primary cells in combination with a 3D biomechanical scaffold, could be used to assess the likelihood of a favorable outcome to tumor treatment, and eventually suggest possible alternative patient-tailored options.

Supplementary Materials: The following supporting information can be downloaded at: https: / /www.mdpi.com/article/10.3390/cells11050824/s1, Figure S1: AFM analysis of patient-derived biopsies.; Figure S2: H\&E characterization of patients' samples.; Figure S3: Physical and pharmaceutical characterization of empty (LIPO) and doxorubicin-loaded liposomes (DOXO-LIPO).; Figure S4: DOXO free and DOXO-LIPO cytotoxic effect on ovarian cancer cell lines in 2D after $48 \mathrm{~h}$ and $72 \mathrm{~h}$ of treatment; Figure S5: DOXO free and DOXO-LIPO cytotoxic effect on ovarian cancer cell lines in 3D MS and NS after $72 \mathrm{~h}$ of treatment.

Author Contributions: F.P. conceived, designed and performed most of the experiments; F.P. wrote the paper and interpreted the data; S.L. performed PCR experiments; S.A.G. supervised AFM experiments; D.G., J.G.P. and L.M. obtained ethical approval for human tissues and performed collection of biopsies from consented OC patients; K.M. performed H\&E on patients biopsies; F.T. and L.F. provided mentoring and contributed the funding support. All authors have read and agreed to the published version of the manuscript.

Funding: Celtic Advanced Life Science Innovation Network, an Ireland Wales 2014-2020 program partially funded by the European Regional Development Fund through the Welsh Government. ERDF funding from CALIN and RISE (c82008). This Project is supported by the Welsh Government's SMART Expertise Programme and is part financed by the European Regional Development Fund (2014-2020 West Wales and the Valleys).

Institutional Review Board Statement: Ethical approval for processing ovarian patient samples has been obtained through Local Research Ethics Committee LREC Wales (ref 15/wa/0065) for the collection of biopsies from consented OC patients.

Informed Consent Statement: Formal written consent was obtained from all patients at the time of recruitment.

Data Availability Statement: Not applicable. 


\begin{abstract}
Acknowledgments: The authors would like to thank: Jianhua Gu, SEM AFM Core: Houston Methodist Hospital Research Institute. Matthew Vasquez, HMRI Microscopy, ACTM Core: Houston Methodist Research Institute. Amanda Weiskoff, Scientific Writer, Academic Affairs: Houston Methodist Academic Institute. Ashley Rivera for making lipid stocks and thin films. This manuscript is dedicated to the memory of Angela Mazzilli and Goiacchino Garrubba and their eagerness for knowledge.
\end{abstract}

Conflicts of Interest: There is no conflict to declare.

\title{
References
}

1. Wei, S.; Fattet, L.; Tsai, J.H.; Guo, Y.; Pai, V.H.; Majeski, H.E.; Chen, A.C.; Sah, R.L.; Taylor, S.S.; Engler, A.; et al. Matrix stiffness drives epithelial-mesenchymal transition and tumour metastasis through a TWIST1-G3BP2 mechanotransduction pathway. Nat. Cell Biol. 2015, 17, 678-688. [CrossRef] [PubMed]

2. Lee, G.; Han, S.-B.; Lee, J.-H.; Kim, H.-W.; Kim, D.-H. Cancer Mechanobiology: Microenvironmental Sensing and Metastasis. ACS Biomater. Sci. Eng. 2019, 5, 3735-3752. [CrossRef] [PubMed]

3. Katira, P.; Bonnecaze, R.T.; Zaman, M.H. Modeling the Mechanics of Cancer: Effect of Changes in Cellular and Extra-Cellular Mechanical Properties. Front. Oncol. 2013, 3, 145. [CrossRef] [PubMed]

4. Zhang, B.; Chen, F.; Xu, Q.; Han, L.; Xu, J.; Gao, L.; Sun, X.; Li, Y.; Li, Y.; Qian, M.; et al. Revisiting ovarian cancer microenvironment: A friend or a foe? Protein Cell 2018, 9, 674-692. [CrossRef] [PubMed]

5. $\quad$ Binnewies, M.; Roberts, E.W.; Kersten, K.; Chan, V.; Fearon, D.F.; Merad, M.; Coussens, L.M.; Gabrilovich, D.I.; Ostrand-Rosenberg, S.; Hedrick, C.C.; et al. Understanding the tumor immune microenvironment (TIME) for effective therapy. Nat. Med. 2018, 24, 541-550. [CrossRef] [PubMed]

6. Lu, P.; Weaver, V.M.; Werb, Z. The extracellular matrix: A dynamic niche in cancer progression. J. Cell Biol. 2012, 196, 395-406 [CrossRef]

7. Suresh, S. Biomechanics and biophysics of cancer cells. Acta Biomater. 2007, 3, 413-438. [CrossRef]

8. Cui, Y.; Hameed, F.M.; Yang, B.; Lee, K.; Pan, C.Q.; Park, S.; Sheetz, M. Cyclic stretching of soft substrates induces spreading and growth. Nat. Commun. 2015, 6, 6333. [CrossRef]

9. Tse, J.M.; Cheng, G.; Tyrrell, J.A.; Wilcox-Adelman, S.A.; Boucher, Y.; Jain, R.K.; Munn, L.L. Mechanical compression drives cancer cells toward invasive phenotype. Proc. Natl. Acad. Sci. USA 2011, 109, 911-916. [CrossRef]

10. Chang, S.F.; Chang, C.A.; Lee, D.Y.; Lee, P.L.; Yeh, Y.M.; Yeh, C.R.; Cheng, C.K.; Chien, S.; Chiu, J.J. Tumor cell cycle arrest induced by shear stress: Roles of integrins and Smad. Proc. Natl. Acad. Sci. USA 2008, 105, 3927-3932. [CrossRef]

11. Charras, G.; Sahai, E. Physical influences of the extracellular environment on cell migration. Nat. Rev. Mol. Cell Biol. 2014, 15, 813-824. [CrossRef] [PubMed]

12. Wirtz, D.; Konstantopoulos, K.; Searson, P.C. The physics of cancer: The role of physical interactions and mechanical forces in metastasis. Nat. Cancer 2011, 11, 512-522. [CrossRef] [PubMed]

13. Rice, A.J.; Cortes, E.; Lachowski, D.; Cheung, B.C.H.; Karim, S.A.; Morton, J.; Hernández, A.D.R. Matrix stiffness induces epithelial-mesenchymal transition and promotes chemoresistance in pancreatic cancer cells. Oncogenesis 2017, 6, e352. [CrossRef] [PubMed]

14. Schrader, J.; Gordon-Walker, T.T.; Aucott, R.L.; Van Deemter, M.; Quaas, A.; Walsh, S.; Benten, D.; Forbes, S.J.; Wells, R.G.; Iredale, J.P. Matrix stiffness modulates proliferation, chemotherapeutic response, and dormancy in hepatocellular carcinoma cells. Hepatology 2011, 53, 1192-1205. [CrossRef]

15. Fan, Y.; Sun, Q.; Li, X.; Feng, J.; Ao, Z.; Li, X.; Wang, J. Substrate Stiffness Modulates the Growth, Phenotype, and Chemoresistance of Ovarian Cancer Cells. Front. Cell Dev. Biol. 2021, 9, 2263. [CrossRef]

16. Nia, H.T.; Munn, L.L.; Jain, R.K. Physical traits of cancer. Science 2020, 370. [CrossRef]

17. Schedin, P.; Keely, P.J. Mammary Gland ECM Remodeling, Stiffness, and Mechanosignaling in Normal Development and Tumor Progression. Cold Spring Harb. Perspect. Biol. 2010, 3, a003228. [CrossRef]

18. Shieh, A.C. Biomechanical Forces Shape the Tumor Microenvironment. Ann. Biomed. Eng. 2011, 39, 1379-1389. [CrossRef]

19. Han, W.; Chen, S.; Yuan, W.; Fan, Q.; Tian, J.; Wang, X.; Chen, L.; Zhang, X.; Wei, W.; Liu, R.; et al. Oriented collagen fibers direct tumor cell intravasation. Proc. Natl. Acad. Sci. USA 2016, 113, 11208-11213. [CrossRef]

20. Winkler, J.; Abisoye-Ogunniyan, A.; Metcalf, K.J.; Werb, Z. Concepts of extracellular matrix remodelling in tumour progression and metastasis. Nat. Commun. 2020, 11, 5120. [CrossRef]

21. Provenzano, P.P.; Inman, D.R.; Eliceiri, K.W.; Knittel, J.G.; Yan, L.; Rueden, C.T.; White, J.G.; Keely, P.J. Collagen density promotes mammary tumor initiation and progression. BMC Med. 2008, 6, 11. [CrossRef] [PubMed]

22. Nadiarnykh, O.; LaComb, R.B.; A Brewer, M.; Campagnola, P.J. Alterations of the extracellular matrix in ovarian cancer studied by Second Harmonic Generation imaging microscopy. BMC Cancer 2010, 10, 94. [CrossRef] [PubMed]

23. Kirkpatrick, N.D.; Brewer, M.A.; Utzinger, U. Endogenous Optical Biomarkers of Ovarian Cancer Evaluated with Multiphoton Microscopy. Cancer Epidemiol. Biomark. Prev. 2007, 16, 2048-2057. [CrossRef] 
24. Williams, R.; Flesken-Nikitin, A.; Ellenson, L.H.; Connolly, D.C.; Hamilton, T.C.; Nikitin, A.Y.; Zipfel, W. Strategies for High Resolution Imaging of Epithelial Ovarian Cancer by Laparoscopic Nonlinear Microscopy. Transl. Oncol. 2010, 3, 181-194. [CrossRef] [PubMed]

25. Freedman, R.S.; Deavers, M.; Liu, J.; Wang, E. Peritoneal inflammation - A microenvironment for Epithelial Ovarian Cancer (EOC). J. Transl. Med. 2004, 2, 10-23. [CrossRef] [PubMed]

26. Nezhat, F.; Datta, M.S.; Hanson, V.; Pejovic, T.; Nezhat, C.; Nezhat, C. The relationship of endometriosis and ovarian malignancy: A review. Fertil. Steril. 2008, 90, 1559-1570. [CrossRef]

27. Erickson, B.K.; Conner, M.G.; Landen, C.N. The role of the fallopian tube in the origin of ovarian cancer. Am. J. Obstet. Gynecol. 2013, 209, 409-414. [CrossRef] [PubMed]

28. Klotz, D.M.; Wimberger, P. Cells of origin of ovarian cancer: Ovarian surface epithelium or fallopian tube? Arch. Gynecol. Obstet. 2017, 296, 1055-1062. [CrossRef]

29. Shield, K.; Ackland, L.; Ahmed, N.; Rice, G. Multicellular spheroids in ovarian cancer metastases: Biology and pathology. Gynecol. Oncol. 2009, 113, 143-148. [CrossRef]

30. Naora, H.; Montell, D.J. Ovarian Cancer Metastasis: Integrating insights from disparate model organisms. Nat. Cancer 2005, 5, 355-366. [CrossRef]

31. Novak, C.; Horst, E.; Mehta, G. Review: Mechanotransduction in ovarian cancer: Shearing into the unknown. APL Bioeng. 2018, 2, 031701. [CrossRef] [PubMed]

32. Lengyel, E. Ovarian Cancer Development and Metastasis. Am. J. Pathol. 2010, 177, 1053-1064. [CrossRef] [PubMed]

33. Kim, S.; Kim, B.; Song, Y.S. Ascites modulates cancer cell behavior, contributing to tumor heterogeneity in ovarian cancer. Cancer Sci. 2016, 107, 1173-1178. [CrossRef] [PubMed]

34. Qu, Y.; He, Y.; Li, Z.; Chen, X.; Liu, Q.; Zou, S.; Kong, C.; Liu, Y.; Gao, C.; Zhang, G.; et al. Constructing an ovarian cancer metastasis index by dissecting medical records. Oncotarget 2017, 8, 102212-102222. [CrossRef] [PubMed]

35. Agarwal, R.; Kaye, S.B. Ovarian cancer: Strategies for overcoming resistance to chemotherapy. Nat. Rev. Cancer 2003, 3, 502-516. [CrossRef]

36. Kim, A.; Ueda, Y.; Naka, T.; Enomoto, T. Therapeutic strategies in epithelial ovarian cancer. J. Exp. Clin. Cancer Res. 2012, 31, 14-18. [CrossRef]

37. Pignata, S.; De Placido, S.; Biamonte, R.; Scambia, G.; Di Vagno, G.; Colucci, G.; Febbraro, A.; Marinaccio, M.; Lombardi, A.V.; Manzione, L.; et al. Residual neurotoxicity in ovarian cancer patients in clinical remission after first-line chemotherapy with carboplatin and paclitaxel: The Multicenter Italian Trial in Ovarian cancer (MITO-4) retrospective study. BMC Cancer 2006, 6, 5. [CrossRef]

38. Abraham, S.A.; Waterhouse, D.N.; Mayer, L.D.; Cullis, P.R.; Madden, T.D.; Bally, M.B. The Liposomal Formulation of Doxorubicin In Methods in Enzymology; Academic Press: Cambridge, MA, USA, 2005; Volume 391, pp. 71-97. [CrossRef]

39. Staropoli, N.; Ciliberto, D.; Botta, C.; Fiorillo, L.; Grimaldi, A.; Lama, S.; Caraglia, M.; Salvino, A.; Tassone, P.; Tagliaferri, P. Pegylated liposomal doxorubicin in the management of ovarian cancer: A systematic review and metaanalysis of randomized trials. Cancer Biol. Ther. 2014, 15, 707-720. [CrossRef]

40. Gordon, A.N.; Fleagle, J.T.; Guthrie, D.; Parkin, D.E.; Gore, M.E.; Lacave, A.J. Recurrent Epithelial Ovarian Carcinoma: A Randomized Phase III Study of Pegylated Liposomal Doxorubicin Versus Topotecan. J. Clin. Oncol. 2001, 19, 3312-3322. [CrossRef]

41. Weng, C.-S.; Wu, C.-C.; Chen, T.-C.; Chen, J.-R.; Huang, C.-Y.; Chang, C.-L. Retrospective Analysis Of Comparative Outcomes In Recurrent Platinum-Sensitive Ovarian Cancer Treated With Pegylated Liposomal Doxorubicin (Lipo-Dox) And Carboplatin Versus Paclitaxel And Carboplatin. Cancer Manag. Res. 2019, 11, 9899-9905. [CrossRef]

42. Acerbi, I.; Cassereau, L.; Dean, I.; Shi, Q.; Au, A.; Park, C.; Chen, Y.Y.; Liphardt, J.; Hwang, E.S.; Weaver, V.M. Human breast cancer invasion and aggression correlates with ECM stiffening and immune cell infiltration. Integr. Biol. 2015, 7, 1120-1134 [CrossRef] [PubMed]

43. Caja, L.; Dituri, F.; Mancarella, S.; Caballero-Diaz, D.; Moustakas, A.; Giannelli, G.; Fabregat, I. TGF- $\beta$ and the Tissue Microenvironment: Relevance in Fibrosis and Cancer. Int. J. Mol. Sci. 2018, 19, 1294. [CrossRef]

44. McKenzie, A.J.; Hicks, S.R.; Svec, K.V.; Naughton, H.; Edmunds, Z.L.; Howe, A.K. The mechanical microenvironment regulates ovarian cancer cell morphology, migration, and spheroid disaggregation. Sci. Rep. 2018, 8, 7228. [CrossRef] [PubMed]

45. McGrail, D.J.; Kieu, Q.M.N.; Dawson, M.R. The malignancy of metastatic ovarian cancer cells is increased on soft matrices through a mechanosensitive Rho-ROCK pathway. J. Cell Sci. 2014, 127, 2621-2626. [CrossRef] [PubMed]

46. Paradiso, F.; Serpelloni, S.; Francis, L.W.; Taraballi, F. Mechanical Studies of the Third Dimension in Cancer: From 2D to 3D Model. Int. J. Mol. Sci. 2021, 22, 10098. [CrossRef] [PubMed]

47. Huh, D.; Hamilton, G.A.; Ingber, D.E. From 3D cell culture to organs-on-chips. Trends Cell Biol. 2011, 21, 745-754. [CrossRef]

48. Gu, L.; Mooney, D.J. Biomaterials and emerging anticancer therapeutics: Engineering the microenvironment. Nat. Cancer 2015, 16, 56-66. [CrossRef]

49. O'Brien, F.J. Biomaterials \& scaffolds for tissue engineering. Mater. Today 2011, 14, 88-95. [CrossRef]

50. Han, F.; Wang, J.; Ding, L.; Hu, Y.; Li, W.; Yuan, Z.; Guo, Q.; Zhu, C.; Yu, L.; Wang, H.; et al. Tissue Engineering and Regenerative Medicine: Achievements, Future, and Sustainability in Asia. Front. Bioeng. Biotechnol. 2020, 8, 83. [CrossRef] 
51. Akter, F. Principles of Tissue Engineering. In Tissue Engineering Made Easy; Akter, F., Ed.; Academic Press: Cambridge, MA, USA, 2016; pp. 3-16.

52. Nii, T.; Katayama, Y. Biomaterial-Assisted Regenerative Medicine. Int. J. Mol. Sci. 2021, 22, 8657. [CrossRef] [PubMed]

53. Almouemen, N.; Kelly, H.M.; O'Leary, C. Tissue Engineering: Understanding the Role of Biomaterials and Biophysical Forces on Cell Functionality Through Computational and Structural Biotechnology Analytical Methods. Comput. Struct. Biotechnol. J. 2019, 17, 591-598. [CrossRef] [PubMed]

54. Mhanna, R.; Hasan, A. Introduction to tissue engineering. In Tissue Engineering for Artificial Organs: Regenerative Medicine, Smart Diagnostics and Personalized Medicine; John Wiley \& Sons, Inc.: Hoboken, NJ, USA, 2017; pp. 1-34.

55. Qu, H.; Fu, H.; Han, Z.; Sun, Y. Biomaterials for bone tissue engineering scaffolds: A review. RSC Adv. 2019, 9, $26252-26262$. [CrossRef]

56. Groeber, F.; Holeiter, M.; Hampel, M.; Hinderer, S.; Schenke-Layland, K. Skin tissue engineering — In vivo and in vitro applications. Adv. Drug Deliv. Rev. 2011, 63, 352-366. [CrossRef] [PubMed]

57. Peña, B.; Laughter, M.; Jett, S.; Rowland, T.J.; Taylor, M.R.G.; Mestroni, L.; Park, D. Injectable Hydrogels for Cardiac Tissue Engineering. Macromol. Biosci. 2018, 18, e1800079. [CrossRef]

58. Kwee, B.J.; Mooney, D.J. Biomaterials for skeletal muscle tissue engineering. Curr. Opin. Biotechnol. 2017, 47, 16-22. [CrossRef]

59. Nii, T.; Makino, K.; Tabata, Y. Three-Dimensional Culture System of Cancer Cells Combined with Biomaterials for Drug Screening. Cancers 2020, 12, 2754. [CrossRef]

60. Sawadkar, P.; Mandakhbayar, N.; Patel, K.D.; Buitrago, J.O.; Kim, T.H.; Rajasekar, P.; Lali, F.; Kyriakidis, C.; Rahmani, B.; Mohanakrishnan, J.; et al. Three dimensional porous scaffolds derived from collagen, elastin and fibrin proteins orchestrate adipose tissue regeneration. J. Tissue Eng. 2021, 12. [CrossRef]

61. Smith, G.N.; Bairati, A.; Garrone, R. Biology of Invertebrate and Lower Vertebrate Collagens. Estuaries 1986, 9, 229. [CrossRef]

62. Ricard-Blum, S. The collagen family. Cold Spring Harb. Perspect. Biol. 2011, 3, 4978. [CrossRef]

63. Chan, B.P.; Leong, K.W. Scaffolding in tissue engineering: General approaches and tissue-specific considerations. Eur. Spine J. 2008, 17, 467-479. [CrossRef] [PubMed]

64. Hollister, S.J. Porous scaffold design for tissue engineering. Nat. Mater. 2005, 4, 518-524. [CrossRef]

65. Chen, H.; Han, Q.; Wang, C.; Liu, Y.; Chen, B.; Wang, J. Porous Scaffold Design for Additive Manufacturing in Orthopedics: A Review. Front. Bioeng. Biotechnol. 2020, 8, 609. [CrossRef] [PubMed]

66. Lin, S.; Gu, L. Influence of Crosslink Density and Stiffness on Mechanical Properties of Type I Collagen Gel. Materials 2015, 8 , 551-560. [CrossRef]

67. Mullen, C.; Haugh, M.; Schaffler, M.; Majeska, R.; McNamara, L. Osteocyte differentiation is regulated by extracellular matrix stiffness and intercellular separation. J. Mech. Behav. Biomed. Mater. 2013, 28, 183-194. [CrossRef]

68. Grover, C.N.; Gwynne, J.H.; Pugh, N.; Hamaia, S.; Farndale, R.W.; Best, S.M.; Cameron, R.E. Crosslinking and composition influence the surface properties, mechanical stiffness and cell reactivity of collagen-based films. Acta Biomater. 2012, 8, 3080-3090. [CrossRef]

69. Paradiso, F.; Quintela, M.; Lenna, S.; Serpelloni, S.; James, D.; Caserta, S.; Conlan, S.; Francis, L.; Taraballi, F. Studying Activated Fibroblast Phenotypes and Fibrosis-Linked Mechanosensing Using 3D Biomimetic Models. Macromol. Biosci. 2022, 2100450. [CrossRef]

70. Taraballi, F.; Corradetti, B.; Minardi, S.; Powel, S.; Cabrera, F.; Van Eps, J.L.; Weiner, B.K.; Tasciotti, E. Biomimetic collagenous scaffold to tune inflammation by targeting macrophages. J. Tissue Eng. 2016, 7. [CrossRef]

71. Minardi, S.; Corradetti, B.; Taraballi, F.; Sandri, M.; Van Eps, J.; Cabrera, F.; Weiner, B.K.; Tampieri, A.; Tasciotti, E. Evaluation of the osteoinductive potential of a bio-inspired scaffold mimicking the osteogenic niche for bone augmentation. Biomaterials 2015, 62, 128-137. [CrossRef]

72. Corradetti, B.; Taraballi, F.; Corbo, C.; Cabrera, F.; Pandolfi, L.; Minardi, S.; Wang, X.; Van Eps, J.; Bauza, G.; Weiner, B.; et al Immune tuning scaffold for the local induction of a pro-regenerative environment. Sci. Rep. 2017, 7, 17030. [CrossRef] [PubMed]

73. Corradetti, B.; Taraballi, F.; Minardi, S.; Van Eps, J.; Cabrera, F.; Francis, L.W.; Gazze, S.A.; Ferrari, M.; Weiner, B.K.; Tasciotti, E. Chondroitin Sulfate Immobilized on a Biomimetic Scaffold Modulates Inflammation While Driving Chondrogenesis. STEM CELLS Transl. Med. 2016, 5, 670-682. [CrossRef] [PubMed]

74. Minardi, S.; Sandri, M.; Martinez, J.; Yazdi, I.; Liu, X.; Ferrari, M.; Weiner, B.K.; Tampieri, A.; Tasciotti, E. Multiscale Patterning of a Biomimetic Scaffold Integrated with Composite Microspheres. Small 2014, 10, 3943-3953. [CrossRef] [PubMed]

75. Fischbach, C.; Chen, R.; Matsumoto, T.; Schmelzle, T.; Brugge, J.S.; Polverini, P.J.; Mooney, D. Engineering tumors with 3D scaffolds. Nat. Methods 2007, 4, 855-860. [CrossRef] [PubMed]

76. Ma, Y.J.; Bryce, N.S.; Whan, R.M.; Xiao, L.; Li, K.; Ruys, A.J.; Hambley, T.W.; Boughton, P. Growth of DLD-1 Colon Cancer Cells on Variotis ${ }^{\mathrm{TM}}$ Scaffolds of Controlled Porosity: A Preliminary Study. J. Biomim. Biomater. Tissue Eng. 2010, 8, 79-89. [CrossRef]

77. Le, M.N.; Xu, K.; Wang, Z.; Beverung, S.; Steward, R.L.; Florczyk, S.J. Evaluation of the effect of 3D porous Chitosan-alginate scaffold stiffness on breast cancer proliferation and migration. J. Biomed. Mater. Res. Part A 2021, 109, 1990-2000. [CrossRef]

78. Xu, K.; Ganapathy, K.; Andl, T.; Wang, Z.; Copland, J.A.; Chakrabarti, R.; Florczyk, S.J. 3D porous chitosan-alginate scaffold stiffness promotes differential responses in prostate cancer cell lines. Biomaterials 2019, 217, 119311. [CrossRef]

79. Florczyk, S.; Kievit, F.M.; Wang, K.; Erickson, A.E.; Ellenbogen, R.G.; Zhang, M. 3D porous chitosan-alginate scaffolds promote proliferation and enrichment of cancer stem-like cells. J. Mater. Chem. B 2016, 4, 6326-6334. [CrossRef] 
80. Florczyk, S.; Liu, G.; Kievit, F.; Lewis, A.M.; Wu, J.D.; Zhang, M. 3D Porous Chitosan-Alginate Scaffolds: A New Matrix for Studying Prostate Cancer Cell-Lymphocyte Interactions In Vitro. Adv. Health Mater. 2012, 1, 590-599. [CrossRef]

81. Florczyk, S.; Wang, K.; Jana, S.; Wood, D.L.; Sytsma, S.K.; Sham, J.G.; Kievit, F.; Zhang, M. Porous chitosan-hyaluronic acid scaffolds as a mimic of glioblastoma microenvironment ECM. Biomaterials 2013, 34, 10143-10150. [CrossRef]

82. Xu, W.; Mezencev, R.; Kim, B.; Wang, L.; McDonald, J.F.; Sulchek, T. Cell Stiffness Is a Biomarker of the Metastatic Potential of Ovarian Cancer Cells. PLoS ONE 2012, 7, e46609. [CrossRef] [PubMed]

83. Mathieu, S.; Manneville, J.-B. Intracellular mechanics: Connecting rheology and mechanotransduction. Curr. Opin. Cell Biol. 2018, 56, 34-44. [CrossRef] [PubMed]

84. Svenson, S. Clinical translation of nanomedicines. Curr. Opin. Solid State Mater. Sci. 2012, 16, 287-294. [CrossRef]

85. Deptuła, P.; Łysik, D.; Pogoda, K.; Cieśluk, M.; Namiot, A.; Mystkowska, J.; Król, G.; Głuszek, S.; Janmey, P.A.; Bucki, R. Tissue Rheology as a Possible Complementary Procedure to Advance Histological Diagnosis of Colon Cancer. ACS Biomater. Sci. Eng. 2020, 6, 5620-5631. [CrossRef]

86. Fogh, J.; Fogh, J.M.; Orfeo, T. One hundred and twenty-seven cultured human tumor cell lines producing tumors in nude mice. J. Natl. Cancer Inst. 1977, 59, 221-226. [CrossRef]

87. Zanconato, F.; Cordenonsi, M.; Piccolo, S. YAP/TAZ at the Roots of Cancer. Cancer Cell 2016, 29, 783-803. [CrossRef]

88. Sudol, M. YAP1 oncogene and its eight isoforms. Oncogene 2012, 32, 3922. [CrossRef]

89. Lee, K.-W.; Lee, S.S.; Kim, S.-B.; Sohn, B.H.; Lee, H.-S.; Jang, H.-J.; Park, Y.-Y.; Kopetz, S.; Kim, S.S.; Oh, S.C.; et al. Significant Association of Oncogene YAP1 with Poor Prognosis and Cetuximab Resistance in Colorectal Cancer Patients. Clin. Cancer Res. 2014, 21, 357-364. [CrossRef]

90. Nguyen, C.D.; Yi, C. YAP/TAZ Signaling and Resistance to Cancer Therapy. Trends Cancer 2019, 5, 283-296. [CrossRef]

91. Gibson, J.; Alzghari, S.; Ahn, C.; Trantham, H.; La-Beck, N. The Role of Pegylated Liposomal Doxorubicin in Ovarian Cancer: A Meta-Analysis of Randomized Clinical Trials. Oncology 2013, 18, 1022-1031. [CrossRef]

92. Zinger, A.; Baudo, G.; Naoi, T.; Giordano, F.; Lenna, S.; Massaro, M.; Ewing, A.; Kim, H.R.; Tasciotti, E.; Yustein, J.T.; et al Reproducible and Characterized Method for Ponatinib Encapsulation into Biomimetic Lipid Nanoparticles as a Platform for Multi-Tyrosine Kinase-Targeted Therapy. ACS Appl. Bio Mater. 2020, 3, 6737-6745. [CrossRef] [PubMed]

93. Molinaro, R.; Martinez, J.O.; Zinger, A.; De Vita, A.; Storci, G.; Arrighetti, N.; De Rosa, E.; Hartman, K.A.; Basu, N.; Taghipour, N.; et al. Leukocyte-mimicking nanovesicles for effective doxorubicin delivery to treat breast cancer and melanoma. Biomater. Sci. 2019, 8, 333-341. [CrossRef] [PubMed]

94. Nagelkerke, A.; Bussink, J.; Rowan, A.E.; Span, P.N. The mechanical microenvironment in cancer: How physics affects tumours. Semin. Cancer Biol. 2015, 35, 62-70. [CrossRef] [PubMed]

95. Jonietz, E. Mechanics: The forces of cancer. Nature 2012, 491, S56-S57. [CrossRef]

96. Zhang, J.; Reinhart-King, C.A. Targeting Tissue Stiffness in Metastasis: Mechanomedicine Improves Cancer Therapy. Cancer Cell 2020, 37, 754-755. [CrossRef]

97. Stewart, D.C.; Rubiano, A.; Dyson, K.; Simmons, C. Mechanical characterization of human brain tumors from patients and comparison to potential surgical phantoms. PLoS ONE 2017, 12, e0177561. [CrossRef]

98. Martino, F.; Perestrelo, A.R.; Vinarsky, V.; Pagliari, S.; Forte, G. Cellular Mechanotransduction: From Tension to Function. Front Physiol. 2018, 9, 824. [CrossRef]

99. Wang, N.; Tytell, J.D.; Ingber, D.E. Mechanotransduction at a distance: Mechanically coupling the extracellular matrix with the nucleus. Nat. Rev. Mol. 2009, 10, 75-82. [CrossRef]

100. Mieulet, V.; Garnier, C.; Kieffer, Y.; Guilbert, T.; Nemati, F.; Marangoni, E.; Renault, G.; Chamming'S, F.; Vincent-Salomon, A.; Mechta-Grigoriou, F. Stiffness increases with myofibroblast content and collagen density in mesenchymal high grade serous ovarian cancer. Sci. Rep. 2021, 11, 4219. [CrossRef]

101. Seewaldt, V. ECM stiffness paves the way for tumor cells. Nat. Med. 2014, 20, 332-333. [CrossRef]

102. Lyshchik, A.; Higashi, T.; Asato, R.; Tanaka, S.; Ito, J.; Hiraoka, M.; Brill, A.; Saga, T.; Togashi, K. Elastic Moduli of Thyroid Tissues under Compression. Ultrason. Imaging 2005, 27, 101-110. [CrossRef] [PubMed]

103. Guimarães, C.F.; Gasperini, L.; Marques, A.P.; Reis, R.L. The stiffness of living tissues and its implications for tissue engineering. Nat. Rev. Mater. 2020, 5, 351-370. [CrossRef]

104. Park, J.S.; Chu, J.S.; Tsou, A.D.; Diop, R.; Tang, Z.; Wang, A.; Li, S. The effect of matrix stiffness on the differentiation of mesenchymal stem cells in response to TGF- $\beta$. Biomaterials 2011, 32, 3921-3930. [CrossRef]

105. Asano, S.; Ito, S.; Takahashi, K.; Furuya, K.; Kondo, M.; Sokabe, M.; Hasegawa, Y. Matrix stiffness regulates migration of human lung fibroblasts. Physiol. Rep. 2017, 5, e13281. [CrossRef]

106. Domcke, S.; Sinha, R.; Levine, D.A.; Sander, C.; Schultz, N. Evaluating cell lines as tumour models by comparison of genomic profiles. Nat. Commun. 2013, 4, 2126. [CrossRef]

107. Beaufort, C.M.; Helmijr, J.C.A.; Piskorz, A.M.; Hoogstraat, M.; Ruigrok-Ritstier, K.; Besselink, N.; Murtaza, M.; van Ijcken, W.; Heine, A.; Smid, M.; et al. Ovarian Cancer Cell Line Panel (OCCP): Clinical Importance of In Vitro Morphological Subtypes. PLoS ONE 2014, 9, e103988. [CrossRef]

108. Hallas-Potts, A.; Dawson, J.; Herrington, C.S. Ovarian cancer cell lines derived from non-serous carcinomas migrate and invade more aggressively than those derived from high-grade serous carcinomas. Sci. Rep. 2019, 9, 9728. [CrossRef] 
109. Hernandez, L.; Kim, M.K.; Lyle, L.T.; Bunch, K.P.; House, C.D.; Ning, F.; Noonan, A.M.; Annunziata, C.M. Characterization of ovarian cancer cell lines as in vivo models for preclinical studies. Gynecol. Oncol. 2016, 142, 332-340. [CrossRef]

110. Lekka, M. Discrimination between Normal and Cancerous Cells Using AFM. BioNanoScience 2016, 6, 65-80. [CrossRef] [PubMed]

111. Alibert, C.; Goud, B.; Manneville, J.B. Are cancer cells really softer than normal cells? Cell Biol. 2017, 109, 167-189. [CrossRef] [PubMed]

112. Li, Q.; Lee, G.; Ong, C.N.; Lim, C. AFM indentation study of breast cancer cells. Biochem. Biophys. Res. Commun. 2008, 374, 609-613. [CrossRef]

113. Park, S. Nano-mechanical Phenotype as a Promising Biomarker to Evaluate Cancer Development, Progression, and Anti-cancer Drug Efficacy. J. Cancer Prev. 2016, 21, 73-80. [CrossRef] [PubMed]

114. Dupont, S.; Morsut, L.; Aragona, M.; Enzo, E.; Giulitti, S.; Cordenonsi, M.; Zanconato, F.; Le Digabel, J.; Forcato, M.; Bicciato, S.; et al. Role of YAP/TAZ in mechanotransduction. Nature 2011, 474, 179-183. [CrossRef]

115. Zanconato, F.; Cordenonsi, M.; Piccolo, S. YAP and TAZ: A signalling hub of the tumour microenvironment. Nat. Rev. Cancer 2019, 19, 454-464. [CrossRef]

116. Diaz-Martin, J.; López-García, M.; López-García, M.Á.; Romero-Perez, L.; Atienza-Amores, M.R.; Pecero, M.L.; Castilla, M.Á.; Biscuola, M.; Santon, A.; Palacios, J. Nuclear TAZ expression associates with the triple-negative phenotype in breast cancer. Endocr. Relat. Cancer 2015, 22, 443-454. [CrossRef]

117. Kim, H.M.; Jung, W.H.; Koo, J.S. Expression of Yes-associated protein (YAP) in metastatic breast cancer. Int. J. Clin. Exp. Pathol. 2015, 8, 11248-11257.

118. Li, Y.-W.; Shen, H.; Frangou, C.; Yang, N.; Guo, J.; Xu, B.; Bshara, W.; Shepherd, L.; Zhu, Q.; Wang, J.; et al. Characterization of TAZ domains important for the induction of breast cancer stem cell properties and tumorigenesis. Cell Cycle 2015, 14, 146-156. [CrossRef] [PubMed]

119. Skibinski, A.; Breindel, J.L.; Prat, A.; Galván, P.; Smith, E.; Rolfs, A.; Gupta, P.B.; LaBaer, J.; Kuperwasser, C. The Hippo Transducer TAZ Interacts with the SWI/SNF Complex to Regulate Breast Epithelial Lineage Commitment. Cell Rep. 2014, 6, 1059-1072. [CrossRef] [PubMed]

120. Zhang, X.; George, J.; Deb, S.; Degoutin, J.L.; Takano, E.A.; Fox, S.B.; Bowtell, D.D.L.; Harvey, K.F. The Hippo pathway transcriptional co-activator, YAP, is an ovarian cancer oncogene. Oncogene 2011, 30, 2810-2822. [CrossRef] [PubMed]

121. Galluzzi, L.; Senovilla, L.; Vitale, I.; Michels, J.; Martins, I.; Kepp, O.; Castedo, M.; Kroemer, G. Molecular mechanisms of cisplatin resistance. Oncogene 2011, 31, 1869-1883. [CrossRef]

122. Wu, Q.; Guo, J.; Liu, Y.; Zheng, Q.; Li, X.; Wu, C.; Fang, D.; Chen, X.; Ma, L.; Xu, P.; et al. YAP drives fate conversion and chemoresistance of small cell lung cancer. Sci. Adv. 2021, 7. [CrossRef]

123. Kharaishvili, G.; Simkova, D.; Bouchalova, K.; Gachechiladze, M.; Narsia, N.; Bouchal, J. The role of cancer-associated fibroblasts, solid stress and other microenvironmental factors in tumor progression and therapy resistance. Cancer Cell Int. 2014, 14, 41. [CrossRef] [PubMed]

124. Östman, A. The tumor microenvironment controls drug sensitivity. Nat. Med. 2012, 18, 1332-1334. [CrossRef] [PubMed]

125. NCCN. Treatment by Cancer Type. 2016. Available online: https://www.nccn.org/guidelines/category_1 (accessed on 3 June 2016).

126. Ozols, R.F.; Bundy, B.N.; Greer, B.E.; Fowler, J.M.; Clarke-Pearson, D.; Burger, R.A.; Mannel, R.S.; DeGeest, K.; Hartenbach, E.M.; Baergen, R.; et al. Phase III Trial of Carboplatin and Paclitaxel Compared With Cisplatin and Paclitaxel in Patients With Optimally Resected Stage III Ovarian Cancer: A Gynecologic Oncology Group Study. J. Clin. Oncol. 2003, 21, 3194-3200. [CrossRef] [PubMed]

127. Luvero, D.; Milani, A.; Ledermann, J.A. Treatment options in recurrent ovarian cancer: Latest evidence and clinical potential. Ther. Adv. Med. Oncol. 2014, 6, 229-239. [CrossRef] [PubMed]

128. Bookman, M.A. Extending the Platinum-Free Interval in Recurrent Ovarian Cancer: The Role of Topotecan in Second-Line Chemotherapy. Oncologist 1999, 4, 87-94. [CrossRef]

129. Pignata, S.; Scambia, G.; Bologna, A.; Signoriello, S.; Vergote, I.B.; Wagner, U.; Lorusso, D.; Murgia, V.; Sorio, R.; Ferrandina, G.; et al. Randomized Controlled Trial Testing the Efficacy of Platinum-Free Interval Prolongation in Advanced Ovarian Cancer: The MITO-8, MaNGO, BGOG-Ov1, AGO-Ovar2.16, ENGOT-Ov1, GCIG Study. J. Clin. Oncol. 2017, 35, 3347-3353. [CrossRef] [PubMed]

130. Tomao, F.; D'Incalci, M.; Biagioli, E.; Peccatori, F.A.; Colombo, N. Restoring platinum sensitivity in recurrent ovarian cancer by extending the platinum-free interval: Myth or reality? Cancer 2017, 123, 3450-3459. [CrossRef]

131. Zang, R.; Zhu, J. Which patients benefit from secondary cytoreductive surgery in recurrent ovarian cancer? J. Gynecol. Oncol. 2019, 30. [CrossRef]

132. Barenholz, Y.C. Doxilß—the first FDA-approved nano-drug: Lessons learned. J. Control. Release 2012, 160, pp.117-134. [CrossRef]

133. Yuan, Z.; Zhang, Y.; Cao, D.; Shen, K.; Li, Q.; Zhang, G.; Wu, X.; Cui, M.; Yue, Y.; Cheng, W.; et al. Pegylated liposomal doxorubicin in patients with epithelial ovarian cancer. J. Ovarian Res. 2021, 14, 12. [CrossRef] [PubMed]

134. Pisano, C.; Cecere, S.C.; Di Napoli, M.; Cavaliere, C.; Tambaro, R.; Facchini, G.; Scaffa, C.; Losito, S.; Pizzolorusso, A.; Pignata, S. Clinical Trials with Pegylated Liposomal Doxorubicin in the Treatment of Ovarian Cancer. J. Drug Deliv. 2013, 2013, 898146. [CrossRef] [PubMed] 
135. Sun, X.; Wang, S.; Gai, J.; Guan, J.; Li, J.; Li, Y.; Zhao, J.; Zhao, C.; Fu, L.; Li, Q. SIRT5 promotes cisplatin resistance in ovarian cancer by suppressing DNA damage in a ROS-dependent manner via regulation of the Nrf2/HO-1 pathway. Front. Oncol. 2019, 9, 754. [CrossRef] [PubMed]

136. Kim, M.-G.; Pak, J.H.; Choi, W.H.; Park, J.-Y.; Nam, J.-H.; Kim, J.-H. The relationship between cisplatin resistance and histone deacetylase isoform overexpression in epithelial ovarian cancer cell lines. J. Gynecol. Oncol. 2012, 23, 182-189. [CrossRef] [PubMed]

137. Tsunetoh, S.; Terai, Y.; Sasaki, H.; Tanabe, A.; Tanaka, Y.; Sekijima, T.; Fujioka, S.; Kawaguchi, H.; Kanemura, M.; Yamashita, Y.; et al. Topotecan as a molecular targeting agent which blocks the Akt and VEGF cascade in platinum-resistant ovarian cancers. Cancer Biol. Ther. 2010, 10, 1137-1146. [CrossRef]

138. Ebata, T.; Mitsui, Y.; Sugimoto, W.; Maeda, M.; Araki, K.; Machiyama, H.; Harada, I.; Sawada, Y.; Fujita, H.; Hirata, H.; et al. Substrate Stiffness Influences Doxorubicin-Induced p53 Activation via ROCK2 Expression. BioMed Res. Int. 2017, $2017,5158961$. [CrossRef] 